UC-33A

Issued: May 1986

LA--10710-MS

DE86 013624

\title{
General-Purpose Heat Source Safety Verification Test Series: SVT-11 Through SVT-13
}

\author{
T. G. George \\ D. Pavone
}

\section{DISCLAIMER}

\begin{abstract}
This report was prepared as an account of work sponsored by an agency of the United State Government. Neither the United States Government nor any agency thereof, nor any of their bility for the accuracy, completenese, or ur implied, or assumes any legal liability or responsiprocess discloaed, or represents that its use ence herein to any specific commercial product, prot infringe privateiy owned rights. Refermanufacturer, or otherwise does not necessarily const, or service by trade name, trademark, mendation, or favoriag by the United States Gonstitute or imply its endorsement, recomand opinions of authors expressed hereintes Government or any agency thereof. The views United States Government or any agency thereof.
\end{abstract}




\title{
GENERAL-PLRPOSE HEAT SOURCE \\ SAFETY VERIFICATION TEST SERIES: SVT-11 THROUGH SVT-13
}

\author{
by
}

\author{
T. G. George and D. Pavone
}

\begin{abstract}
The General-Purpose Heat Source (GPHS) is a modular component of the radioisotope thermoelectric generator that will provide power for the Galileo and Ulysses (formerly ISPM) space missions. The GPHS provides power by transmitting the heat of ${ }^{238} \mathrm{Pu} \alpha$-decay to an array of thermoelectric elements. Because the possibility of an orbital abort always exists, the heat source was designed and constructed to minimize plutenia release in any accident environment. The Safety Verification Test (SVT) series was formulated to evaluate the effectiveness of GPHS piutonia containment after atmospheric reentry and Earth impact. The first two reports (covering SVT-1 through SVT-10) described the results of flat, side-on, and angular module impacts against steel targets at $54 \mathrm{~m} / \mathrm{s}$. This report describes flat-on module impacts against concrete and granite targets, at velocities equivalent to or higher than previous SVTs.
\end{abstract}

\section{INTRODUCTION}

The General-Purpose Heat Source (GPHS) is a moc ular component of the radioisotope thermoelectric generator (RTG) that will provide power for the NASA Galileo and ESA Ulysses (formerly ISPM) space missions. The RTG generates electric power by using the heat of ${ }^{238} \mathrm{Pu} a$-decay to create a temperature differential across a thermoelectric array. The Galileo mission sill require two RTGs, and Ulysses will use a single RTG. Each RTG will contain 18 GPHS modules.

The prototype GPHS module was designed by Los Alamos National Laboratory and modified by the General Electric Company, Inc., (system contractor for the RTG) to meet weight requirements of the Galileo and Ulysses missions. Each GPHS module contains four ${ }^{238} \mathrm{PuO}_{2}$ fuel pellets that provide a total thermal cutput of $250 \mathrm{~W}$. Each fuel pellet is encapsulated in a vented, DOP-26 iridium alloy shell. Two capsules are held in a Fineweave-Pierced Fabric* (FWPF) graphite impact

\footnotetext{
* Fineweave-Pierced Fabric 3-D carbon/carbon composite, a product of AVCO Systems Division, 201 Lowell St., Wilmington, MA 01887.
}

shell (GIS), and two GISs are contained within a FWPF aeroshell. A schematic of the GPHS module is shown in Fig. 1. Because the possibility of an orbital abort always exists, the GPHS module has been designed to minimize plutonia release during atmospheric reentry and Earth impact.

Accident analyses have shown that in any orbital abort (apart from an abort resulting from an in-flight explosion), the GPHS modules would be released from the RTG early in reentry and would strike the Earth singly and intact. ${ }^{1}$ The responses of GPHS modules with various processing histories to a variety of reentry and impact conditions were investigated in the Design Iteration Tests (DITs). ${ }^{2}$ With the completion of the DITs, emphasis shifted to verifying the survivability of GPHS modules in probable accident environments. The objective of the Safety Verification Test (SVT) series was to determine the response of the GPIS module and its components to atmospheric reentry and Earth impact. ${ }^{3}$

The first 10 SVTs investigated module response in a series of flat, side-or, and angular impacts against steel targets; these tests were described in previous reports. 4,5 The final three SVTs (tests 11 through 13) were designed to evaluate the effects of other target materials and higher impact velocities. A schematic of the flat-on 


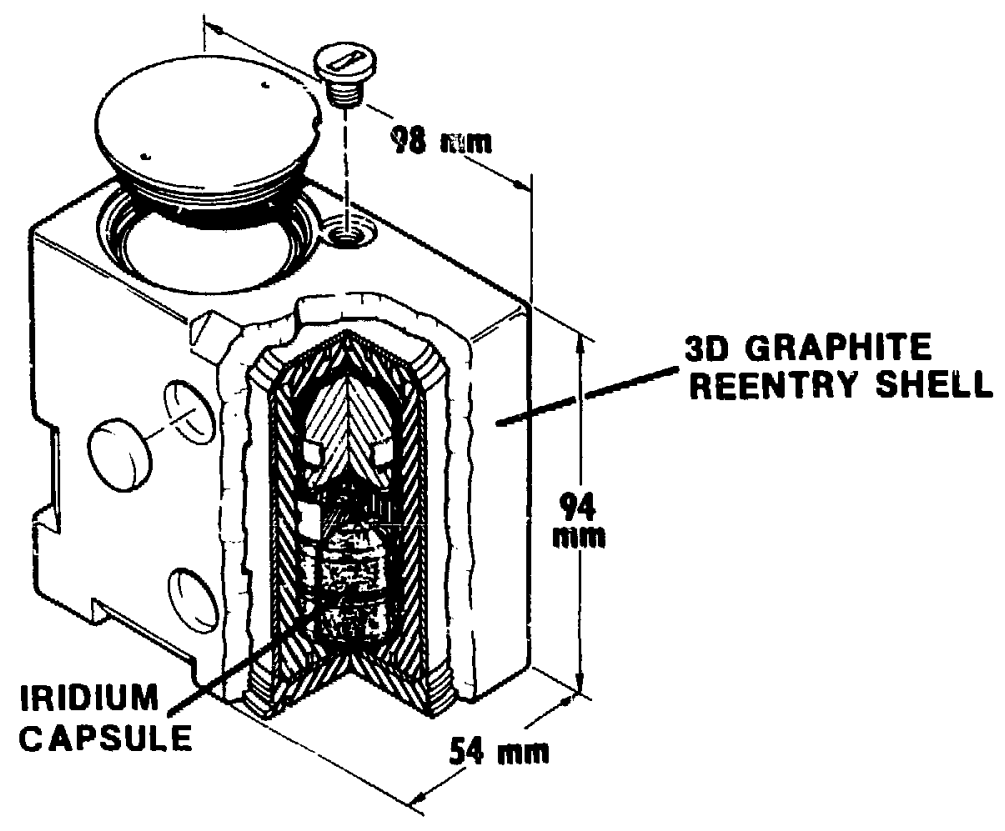

Fig. 1. The GPHS module.

module orientation used in all three tests may be seen in Fig. 2.

\section{TEST PROGRAM}

The SVT test program was designed to simulate the atmospheric reentry and subsequent Earth impact experienced by a GPHS module in the aftermath of an orbital abort. The impact orientation of each test module was determined by a technical review board consisting of R. W. Zocher (Los Alamos National Laboratory), C. T. Bradshaw (GE), and R. W. Englehart (NUS). Thirteen GPHS modules were allocated for the test series.
The test modules were assembled at the Monsanto Research Corporation (MRC) and were treated (to reduce the excess oxygen content of the plutonia fuel) in the Mound Reduction and Monitoring Facility (MRMF). The treated modules were then subjected to two cycles of flight-acceptance vibration spectra and transient accelerations, radiographed, and shipped to Los Alamos. Components of the GPHS modules used in SVT-11 through SVT-13 are identified in Table I.

The plutonia fuel pellets required for the SVT impacts were fabricated and encapsulated in iridium at the Savannah River Plant (SRP). The iridium shells were fabricated by the Mound Plant from iridium alloy blanks supplied by the Oak Ridge National Laboratory (ORNL). A process change during production resulted

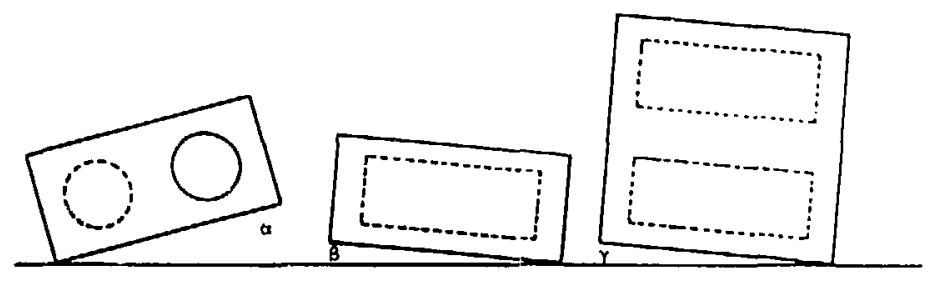

Fig. 2. All of the test assemblies were impacted flat-on $(\alpha=\beta=\gamma=0)$. 


\begin{tabular}{|c|c|c|c|}
\hline Component & SVT-11 & SVT-12 & SVT-13 \\
\hline Aeroshell & PAL-010 & PAT-1028 & PAT-1032 \\
\hline $\begin{array}{l}\text { Primary Impact Assembly } \\
\text { Impact shell } \\
\text { Insulation cylinder } \\
\text { Insulation dises }\end{array}$ & $\begin{array}{l}\text { PGL-008 } \\
\text { C-40-3 } \\
\text { P-8-2-15 } \\
\text { P-11-1-17 }\end{array}$ & $\begin{array}{l}\text { PGT-1071 } \\
\text { C-56-4 } \\
\text { P-13-2-34 } \\
\text { P-13-2-37 }\end{array}$ & $\begin{array}{l}\text { PGT-1069 } \\
\text { C-56-1 } \\
\text { P-13-2-39 } \\
\text { P-13-2-32 }\end{array}$ \\
\hline $\begin{array}{l}\text { Fueled Clad } 1 \text { (closure end) } \\
\text { Fuel pellet } \\
\text { Vent cup } \\
\text { Shield cup }\end{array}$ & $\begin{array}{l}\text { FC-372 } \\
\text { HF-372 } \\
\text { QR820-5 } \\
\text { QR821-4 }\end{array}$ & $\begin{array}{l}\text { FC-628 } \\
\text { HF-628 } \\
\text { S-11.1 } \\
\text { TR-121.2 }\end{array}$ & $\begin{array}{l}\text { FC-604 } \\
\text { HF-604 } \\
\text { X-304.1 } \\
\text { X-317.5 }\end{array}$ \\
\hline $\begin{array}{l}\text { Fueled Clad } 2 \text { (blind end) } \\
\text { Fuel pellet } \\
\text { Vent cup } \\
\text { Shield cup }\end{array}$ & $\begin{array}{l}\text { FC-345 } \\
\text { HF-5-45 } \\
\text { LR324-5 } \\
\text { LR324-6 }\end{array}$ & $\begin{array}{l}\text { FC-629 } \\
\text { HF-629 } \\
\text { TR-128.1 } \\
\text { TR-127.5 }\end{array}$ & $\begin{array}{l}\text { FC-605 } \\
\text { HF-605 } \\
\text { X-317.2 } \\
\text { X-317.3 }\end{array}$ \\
\hline $\begin{array}{l}\text { Secondary Impact Assembly } \\
\text { Impact shell } \\
\text { Insulation cylinder } \\
\text { Insulation discs }\end{array}$ & $\begin{array}{l}\text { PGL-012 } \\
\text { C-39-4 } \\
\text { P-12-1-20 } \\
\text { P-11-1-21 }\end{array}$ & $\begin{array}{l}\text { PGT-1072 } \\
\text { C-56-5 } \\
\text { P-13-2-36 } \\
\text { P-13-2-38 }\end{array}$ & $\begin{array}{l}\text { PGT-1070 } \\
\text { C-56-3 } \\
\text { P-13-2-3 } \\
\text { P-13-2-33 }\end{array}$ \\
\hline $\begin{array}{l}\text { Fueled Clad } 3 \text { (closure end) } \\
\text { Fuel pellet } \\
\text { Vent cup } \\
\text { Shield cup }\end{array}$ & $\begin{array}{l}\text { FC-365 } \\
\text { HF-365 } \\
\text { PR727-1 } \\
\text { PR' } 27-4\end{array}$ & $\begin{array}{l}\text { FC-226 } \\
\text { HF-226 } \\
\text { P-703-4 } \\
\text { P-703-5 }\end{array}$ & $\begin{array}{l}\text { FC-526 } \\
\text { HF-526 } \\
\text { SR-57.2 } \\
\text { SR-58.5 }\end{array}$ \\
\hline $\begin{array}{l}\text { Fueled Clad } 4 \text { (blind end) } \\
\text { Fuel pellet } \\
\text { Vent cup } \\
\text { Shield cup }\end{array}$ & $\begin{array}{l}\text { FC-341 } \\
\text { HF-341 } \\
\text { PR725-2 } \\
\text { PR726-3 }\end{array}$ & $\begin{array}{l}\text { FC-277 } \\
\text { HF-277 } \\
\text { R-432-3 } \\
\text { MER-16-6 }\end{array}$ & $\begin{array}{l}\text { FC-546 } \\
\text { HF-546 } \\
\text { X-310.6 } \\
\text { X-309.3 }\end{array}$ \\
\hline
\end{tabular}

in two classes of plutonia pellets, sintered either in an $\mathrm{Ar}$ or an $\mathrm{Ar} / \mathrm{O}_{2}$ atmosphere. Bcth types of pellets are considered to be flight quality; production histories of the fuel pellets used in SVT-11 through SVT-13 are presented in Table II.

All graphite module components were also composed of flight-quality material. ORNL produced the carbonbonded carbon filament (CBCF) insulation, and the FWPF module components were fabricated at Los Alamos and Teledyne Isotopes, Inc., from material provided by MRC. To simulate the ablation resulting from an orbital decay recutry, each FWPF aeroshell was machined at Los Alamos to remove $1.27 \mathrm{~mm}$ of graphite from all external surfaces, which is twice the calculated ablation for an orbital decay reentry.

Each GPHS module contained two flight-quality and two non-flight-quality fueled clads. The flight-quality and non-flight-quality clad Jesignations were provided

\begin{tabular}{|c|c|c|c|}
\hline \multirow[b]{2}{*}{ Pellet No. } & \multirow{2}{*}{$\begin{array}{c}\text { Weight } \\
\text { (g) }\end{array}$} & \multicolumn{2}{|c|}{ Processing Atrmosphere } \\
\hline & & Ar & $\mathrm{Ar} / \mathrm{O}_{2}$ \\
\hline HF-372 & 150.5 & * & \\
\hline HF-345 & 150.5 & $\star$ & \\
\hline HF-365 & 150.4 & $\star$ & \\
\hline HF-341 & 150.6 & $\star$ & \\
\hline$H F-628$ & 149.3 & * & \\
\hline$H F-629$ & 149.4 & * & \\
\hline HF-226 & 150.3 & & * \\
\hline HF-277 & 150.4 & & * \\
\hline HF-604 & 150.2 & * & \\
\hline HF-605 & 150.4 & * & \\
\hline HF-526 & 149.8 & $*$ & \\
\hline HF-546 & 150.3 & * & \\
\hline
\end{tabular}


by SRP. Because cracking occurred in some early test welds, SRP developed an ultrasonic nondestructive evaluation (NDE) technique that rated weld deferts by comparison with a standard defect of known dimensions. Fueled clads with NDE ratings $<8$ (arbitrary units) were designated as flight quality, and capsules with NDE ratings $>8$ were reserved for terrestrial applications where the accident environments are not as severe. In each test module, the flight-quality clads were loaded into a FWPF GIS (the primary impact assembly or PIA) and positioned in the module GIS cavity expected to receive the greatest deformation. Non-flight-quality clads were loaded into a GIS (secondary impact assembly or SIA) and positioned in the remaining GIS cavity.

The concrete targets used for SVT-11 and SVT-12 were fabricated at Los Alamos from 4-ksi concrete. Each target had a thickness of $6.0 \mathrm{in}$. $(152 \mathrm{~mm})$ and a diameter of $7.5 \mathrm{in}$. $(190 \mathrm{~mm})$. However, the effective target diameter in each test was only $7.0 \mathrm{in} .(178 \mathrm{~mm})$, the same size as the catch tube interior.

The granite target used in SVT-13 was purchased from the DoAll Co. oi Des Piaines, Illinois. The target was composed of California black granite, polished to a gage-quality surface finisn. The target had a diameter of $7.5 \mathrm{in} .(190 \mathrm{~mm})$ and a thickness of $4.0 \mathrm{in} .(102 \mathrm{~mm})$. As in the other tests, the effective target diameter was 7.0 in. $(178 \mathrm{~mm})$.

\section{EXPERIMENTAL PROCEDURES}

\section{A. Pretest Data}

The assembled test modules were shipped to Los Alamos in welded stainless steel containers. When received, each container was radiographed to document the condition of the fuel pellets. After radiography the module was removed from the shipping container, disassembled, and macroscopically examined. A $1.60-\mathrm{mm}$ (0.063-in.) pyrometer sight hole was drilled into the cap of the PIA, and both GISs were loaded into a highvaculim furnace for an aging heat treatment.

The aging treatment simulated the temperature of a GPHS module during the orbital decay of an aborted mission. The fueled clads used in SVT-11 through SVT-1 3 were aged for 90 days at $1287^{\circ} \mathrm{C}$, reflecting the maximum time for orbital decay of a Galileo abort and the operating temperature of an orbiting RTG. A!though a Ulysses abort would result in only a 38-day orbital decay, the 90-day decay period was selected to represent both missions. ${ }^{6}$ Helium release from the SVT-11 and SVT-12 test components was monitored throughout the heat treatment; there was no evidence that any of the capsule vents plugged.
After aging, the GISs were prepared for reentry simulation. Holes for a split-junction thermocouple were drilled into the GIS caps. Each GIS was placed in an electron beam furnace and heated through an orbital decay reentry cycle (a schedule of the orbital decay reentry temperatures is presented in Table III). After reentry simulation, the GISs were radiographed a second time and prepared for impact testing.

\section{B. Impact Testing}

After reentry simulation, the GISs were reloaded in to the FWPF aeroshell. To accommedate additional instrumentation, holes were drilled through the aeroshell and impact shell walls. A calibrated split-junction thermocouple was placed in contact widh one of the flight-quality clads, and two beaded-junction thermocouples were attached to the surface of the PIA. The module was then placed inside a $185-\mathrm{mm}$ gas gun at the Los Alamos Isotope Fuels Impact Test Facility. This gun is designed to contain the impacted test article witnin a sealed catch tube. The gun was evacuated, and

\begin{tabular}{|c|c|c|c|}
\hline \multirow{2}{*}{$\begin{array}{c}\text { Table III } \\
\text { Time } \\
\text { (min) } \\
\end{array}$} & \multicolumn{3}{|c|}{ Orbital Decay Reentry Schedule } \\
\hline & $\begin{array}{c}\text { Temperature } \\
\left({ }^{\circ} \mathrm{C}\right)\end{array}$ & $\begin{array}{l}\text { Time } \\
(\min )\end{array}$ & $\begin{array}{c}\text { Temperature } \\
\left({ }^{\circ} \mathrm{C}\right)\end{array}$ \\
\hline 0.00 & 1294 & 10.25 & 1364 \\
\hline 0.50 & 1291 & 10.50 & 1371 \\
\hline 1.00 & 1285 & 10.75 & 1374 \\
\hline 1.50 & 1278 & 11.00 & 1372 \\
\hline 2.00 & 1269 & 11.25 & 1368 \\
\hline 2.50 & 1259 & 11.50 & 1360 \\
\hline 3.00 & 1248 & 11.75 & 1350 \\
\hline $\mathbf{3 . 5 0}$ & 1237 & 12.00 & 1333 \\
\hline 4.00 & 1228 & 12.25 & 1307 \\
\hline 4.50 & 1221 & 12.50 & 1275 \\
\hline 5.00 & 1216 & 12.75 & 1242 \\
\hline 5.50 & 1214 & 13.00 & 1214 \\
\hline 6.00 & 1212 & 13.25 & 1186 \\
\hline 6.50 & 1211 & 13.50 & 1158 \\
\hline 7.00 & 1213 & 13.75 & 1134 \\
\hline 7.50 & 1216 & 14.00 & 1114 \\
\hline 8.00 & 1227 & 14.25 & 1090 \\
\hline 8.50 & 1246 & 14.50 & 1069 \\
\hline 8.75 & 1255 & 14.75 & 1047 \\
\hline 9.00 & 1271 & 15.00 & 1025 \\
\hline 9.25 & 1287 & 15.25 & 1005 \\
\hline 9.50 & 1312 & 15.50 & 983 \\
\hline 9.75 & 1333 & 15.75 & 964 \\
\hline 10.00 & 1349 & & \\
\hline
\end{tabular}


a short series of calibration tests was run to determine the relative GIS and clad temperatures. When the GIS temperature indicative of a $975^{\circ} \mathrm{C}$ clad temperature had been determined, the split-junction thermocouple was removed, and the impact test was run on the basis of the calibrated GIS temperature.

All of the test modules were impacted at $975^{\circ} \mathrm{C}$. In each test, the thermal output of the GPHS module was sufficient to permit self-heating to the test temperature. Specific conditions for each test are listed in Table IV.

\section{Postmortem Examination}

The principal objectives of the postmortem examination were to determine the quantity and particle size of the plutonia release, document the damage sustained by all test components, and characterize the iridium and plutonia impact responses.

After each test, the impacted module, still contained within a sealed catch tube, was transferred to Wing 2 of the CMR building at Los Alamos and was opened. All test components were phoiographed and the fueled clads were measurid to determine the postimpact capsule strains. The size and location of all clad failures and cracks were recorded.

After macroscopic examination, the fueled clads were opened and the patterns of fuel fracture were photographed. At least one unbreached capsule from each test was selected for a particle size analysis; this capsule was opened under water to prevent the loss of small fuel particles.

The capsules were defueled and specimens of each fuel pellet were taken for metallographic and chemical analyses. Fuel pellets selected for particle size analyses were not sampled until after the sieve analyses were completed.

The iridium clads were also sampled to provide specimens for metallographic and chemical analyses. The SVT plan required that each primary clad (the capsules contained within the PIA) be sampled to provide axial and transverse sections of the vent and weld shield cups, a vent cross section, and a weld (single pass region) cross section. In addition, all clad failures and areas of severe localized deformation were sectioned for metallography. The secondary clads were also sampled in cases of clad failure or severe deformation.
All graphitic test components, including the catch tube debris, were analyzed to determine the amount and particle size of plutonia release. The graphite aeroshell, impact shells, and all large pieces of CBCF insulation were ultrasonically cleaned in ethyl alcohol, dried, and burned in air at 850 to $900^{\circ} \mathrm{C}$. The resulting ash was dissolved in acid and radioanalyzed for plutonium. The plutonium content of the graphite test components was assumed to be present as small plutonia fragments $(<10$ $\mu \mathrm{m})$ trapped within the pores of the FWPF graphite.

The ultrasonic cleaning solution was combined with the debris remaining in the catch tube, dried, and burned in oxygen in a plasma-assisted combustion furnace. The plasma-assisted furnace was ustd because its low op:rating temperature $\left(\cong 50^{\circ} \mathrm{C}\right)$ minimized particle agglomeration. The resulting ash was macioscopically examined, and all large pieces of noncombustible material (such as thermocouple wiring, alumina insulation, etc.) were removed. The remaining material was then sized and submitted for radioanalysis.

The plutonia release in SVT-11 was determined by a somewhat different method. Because no capsule failures occurred in this test, the graphite test components and catch tube debris were combined with a solution used to clean the catch tube interior, burned at high temperature, and radioanalyzed for plutonium. All plutonium detected was assumed to have originally been present as $<10-\mu \mathrm{m}$ particles that were vapor transported through the capsule vents.

\section{RESULTS}

The individual SVT impacts and postmortem examinations are summarized below. Analytical results are tabulated as follows:

Table V. SVT Summaries

Table VI. Fuel Release Data

Table VII. Sieve Analyses of Fuel in Unbreached Clads

Table VIII. Grain Size of Selected SVT Clads

Table IX. Iridium AES Analyses

Table X. Iridium Spectrographic Analyses

Table XI. Plutonia Analyses

\begin{tabular}{llccc}
\hline \hline Table IV. & Test Parameters & & & \\
\hline Test & Module Orientation & $\begin{array}{c}\text { Temperature } \\
\left({ }^{\circ} \mathrm{C}\right)\end{array}$ & $\begin{array}{c}\text { Velocity } \\
(\mathrm{m} / \mathrm{s})\end{array}$ & $\begin{array}{c}\text { Target } \\
\text { Material }\end{array}$ \\
\hline SVT-11 $\alpha=\beta=\gamma=0^{\circ}$ & 975 & 54.4 & concrete \\
SVT-12 $\alpha=\beta=\gamma=0^{\circ}$ & 975 & 75.5 & concrete \\
SVT-13 $\alpha=\beta=\gamma=0^{\circ}$ & 975 & 53.4 & granite \\
\hline \hline
\end{tabular}




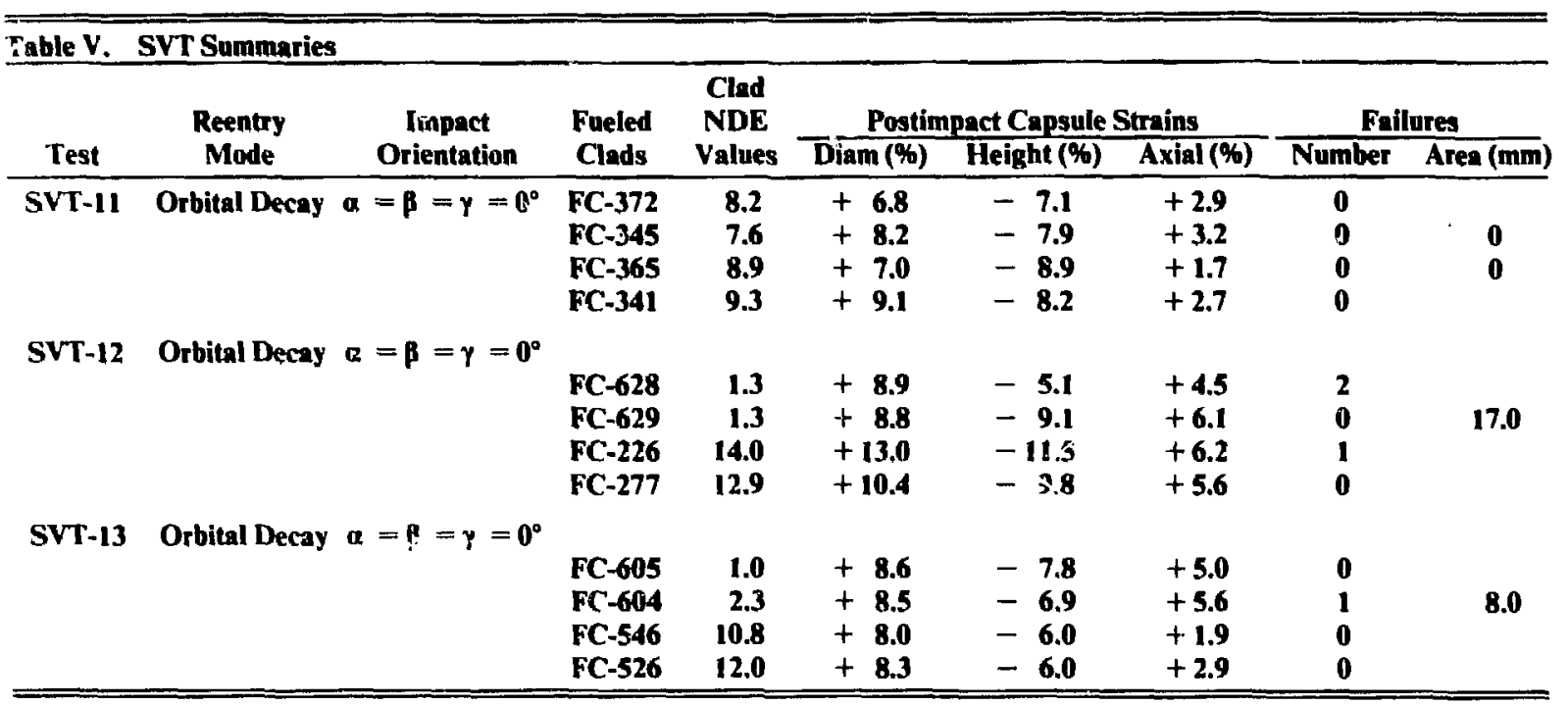

\section{A. SVT-11}

The module was impacted against a concrete target at $54.4 \mathrm{~m} / \mathrm{s}$ and $975^{\circ} \mathrm{C}$. The module orientation was $\alpha=\beta=\gamma=0^{\circ}$.

The module was recovered intact from the catch tube, with the aeroshell closures slightly dislodged. Photographs of the impacted module are shown in Fig. 3. Damage to the FWPF module components was substantially less than that incurred in similar impacts against steel targets. There were no fractures on the aeroshell impact face, but fractures were present on the aeroshell sides parallel to the GIS axes. In addition, the trailing face of the aeroshell was dented and cracked in the center. Figure 4 shows an obliquely illuminated photograph of the concrete target, in which the imprint of the FWPF aeroshell is visible. Although no major fractures of the concrete target were observed, the appearance of the concrete within the module imprint was suggestive of extensive microcracking. Neither GIS fractured on the impact face although such fractures were typically observed in steel target impacts; however each GIS had a slightly bowed profile similar to that seen in all prior tests.

No failures of the iridium capsules were observed. Table $\mathrm{V}$ lists the gross deformations of the fueled clads, which were less than those of capsules impacted against steel targets. The appearance of capsule FC-345 (Fig. 5) was typical of the SVT-11 clads; the clad deformations were generally symmetrical, with little tendency for severe localized iridium deformation at the edges of fuel fragments.
The most severe localized iridium deformation occurred on the center of the FC-345 shield cup impact face. The photomacrograph in Fig. 5 shows two locations of fuel fragment indentation with a shallow reentrant fold. No breaching cracks were detected by metallographic examination.

The iridium cup microstructures were nonuniform across the wall thicknesses. Large grains were observed on the interior $20-25 \%$ of the wall thicknesses. Average transverse and longitudinal grain sizes are tabulated in Table VIII. The grain size of cup QR820-4 (FC-372) was finer than that of the other cups, but all of the cup microstructures were comparable to those of capsules used in previous SVT impacts.

Metallographic examination of the FC-372 and FC-346 closure welds indicated that the welds were of excellent quality. There was no porosity, the weld penetrations were complete, and the microstructures did not exhibit undesirable columnar grains normal to the wall thickness.

Auger electron spectroscopy (AES) analysis of the primary fueled clads (Table IX) revealed severe thorium depletion at the interior in all samples from capsule FC-345 and the FC-372 vent cup. The FC-372 shield cup samples also showed moderate thorium depletion. High sulfur concentrations were also observed at the grain boundaries in three of the four FC-372 samples. The absence of any microstructural anomalies in these specimens suggests that these levels of sulfur do not significantly degrade the iridium.

Iron was the principal impurity detected by spectrographic analysis of the iridium clads. The quantities of 
Table VI. Fuel Release Data

\begin{tabular}{cccc}
\hline & \multicolumn{3}{c}{${ }^{238}$ Pu Release (g) } \\
\cline { 2 - 4 } Test & Total & $\begin{array}{c}<10-\mu \mathrm{m} \\
\text { Fraction }\end{array}$ & $\begin{array}{c}>10-\mu \mathrm{m} \\
\text { Fraction }\end{array}$ \\
\hline SVT-11" & $\mathbf{0 . 0 0 2 7}$ & $\mathbf{0 . 0 0 2 7}$ & 0 \\
SVT-12 & $\mathbf{0 . 0 4 5 8}$ & 6.0377 & 0.0081 \\
SVT-13 & 0.018 & 0.0114 & 0.0069 \\
\hline
\end{tabular}

No clad failures occurred in SVT-11; all fuel release resulted from transport through the capsule vents.

Table VII. Sieve Analyses of Fuel in Unbreached SVT Clads*

\begin{tabular}{|c|c|c|c|}
\hline $\begin{array}{l}\text { Particle Sici } \\
\text { Range ( } \mu \mathrm{m})\end{array}$ & $\begin{array}{c}\text { FC-345 } \\
\text { (SVT-11) }\end{array}$ & $\begin{array}{c}\text { FC-629 } \\
\text { (SVT-12) }\end{array}$ & $\begin{array}{r}\text { FC-605 } \\
\text { (SVT-13) }\end{array}$ \\
\hline $\begin{array}{l}+6000 \\
+2000 \text { to } 6000 \\
+841 \text { to } 2000 \\
+420 \text { to } 841 \\
+177 \text { to } 420 \\
+125 \text { to } 177 \\
+74 \text { to } 125 \\
+44 \text { to } 74 \\
+30 \text { to } 44 \\
+20 \text { to } 30 \\
+10 \text { to } 20 \\
+9 \text { to } 10 \\
+8 \text { to } 9 \\
+7 \text { to } 8 \\
+6 \text { to } 7 \\
+5 \text { to } 6 \\
+4 \text { to } 5 \\
+3 \text { to } 4 \\
+2 \text { to } 3 \\
+1 \text { to } 2 \\
+0 \text { to } 1\end{array}$ & $\begin{array}{l}0.1607 \\
0.3774 \\
0.2477 \\
0.1140 \\
0.0600 \\
0.0093 \\
0.0092 \\
0.0063 \\
0.0040 \\
0.0050 \\
0.0031 \\
0.0008 \\
0.0002 \\
0.0005 \\
0.0004 \\
0.0001 \\
0.0003 \\
0.0002 \\
0.0002 \\
0.0003 \\
0.0003\end{array}$ & $\begin{array}{l}0.2483 \\
0.2357 \\
0.2413 \\
0.1259 \\
0.0741 \\
0.0142 \\
0.0170 \\
0.0136 \\
0.0095 \\
0.0102 \\
0.0058 \\
0.0008 \\
0.0003 \\
0.0008 \\
0.0004 \\
0.0004 \\
0.0004 \\
0.0004 \\
0.0003 \\
0.0003 \\
0.0003\end{array}$ & $\begin{array}{l}0.2112 \\
0.3058 \\
0.2907 \\
0.0978 \\
0.0529 \\
0.0093 \\
0.0093 \\
0.0064 \\
0.0043 \\
0.0052 \\
0.0036 \\
0.0017 \\
0.0005 \\
0.0003 \\
0.0002 \\
0.0002 \\
0.0001 \\
0.0001 \\
0.0001 \\
0.0001 \\
0.0002\end{array}$ \\
\hline $\begin{array}{l}\text { Weight fraction } \\
<10 \mu m\end{array}$ & 0.0033 & 0.0044 & 0.0035 \\
\hline
\end{tabular}

All values are expressed as a fraction of total pellet weight.

iron detected (200-300 ppm) were comparable to those observed in samples from previous test clads. The spectrographic results are tabulated in Table $X$.

Metallographic examination of cross sections through the primary fueled clad vent assemblies indicated that only small quantities of plutonia were deposited at the entrances to the vent filter elements and that the vent orifices were free of nonmetallic deposits. However, abnormally large iridium grains were observed on one side of each vent assembly/decontamination cover weld (Fig. 6).

Results of spectrographic analysis of the plutonia pellets are tabulated in Table XI. The microstructures of plutonia pellets HF-372 and HF-345 were typical of SRP-fabricated material. No second phase impurities were observed in the samples examined.

\section{B. SVT-12}

The SVT-12 test assembly was impacted against a concrete target at $75.5 \mathrm{~m} / \mathrm{s}$ and $975^{\circ} \mathrm{C}$; module orientation was $\alpha=\beta=\gamma=0^{\circ}$. Postimpact examination revealed that the aeroshell (Fig. 7) fractured along the axial contact lines of the GISs and broke into several pieces.

Damage to the GISs was similar to that ouserved in lower velocity impacts. The cap of the primary GIS was removed, and the impact face contained a network of axial cracks running the length of the GIS (Fig. 8). Although the cap was removed, the capsule at the closure end of the primary GIS was not released. The secondary GIS also contained a wide axial crack on the impact face, as well as several small cracks on the other faces (Fig. 9).

Macroscopic examination revealed that one prime (FC-628) and one secondary clad (FC-226) had breached. Both capsules were located on the closure ends of the GISs. Subsequent analysis revealed that $0.0459 \mathrm{~g}$ of plutonium escaped from the breached capsules; of this, $0.0290 \mathrm{~g}$ (approximately 63\%) was released into the catch tube.

All of the SVT-12 clads were severely deformed; capsules FC-628 and FC-226 breached. The impact face of capsule FC- 628 contained two breaching cracks: an axial crack $(14 \mathrm{~mm} \times 0.1 \mathrm{~mm})$ that traversed the weld and extended into both cups (Fig. 10) and a short crack $(3.3 \mathrm{~mm} \times 0.1 \mathrm{~mm})$ on the vent cup radius. Capsule FC-226 breached on the trailing face (Fig. 11), with a wide axial crack $(15.3 \mathrm{~mm} \times 1.0 \mathrm{~mm})$ running the clad length.

Metallographic examination of sections removed from capsule FC-226 revealed surface cracking adjacent to the breach (Fig. 12). Although the breaching crack was exclusively intergranular (Fig. 13), there was evidence of slight grain elongation in shield cup sections adjacent to the breach (Fig. 14). The microscopic appearance of the breaching crack and the amount of clad deformation suggest that the failure resulted from simple stress overload.

Both of the FC- 628 breaches apparently resulted from the differential displacement of fuel pellet fragments. The breaching cracks were exclusively intergranular and occurred with minimal plastic deformation. The shield 


\begin{tabular}{|c|c|c|c|c|c|}
\hline \multirow[b]{2}{*}{ Fueled Clad } & \multirow[b]{2}{*}{ Test } & \multirow{2}{*}{$\begin{array}{l}\text { Iridium } \\
\text { Cup }\end{array}$} & \multicolumn{2}{|c|}{ Grain Size" } & \multirow[b]{2}{*}{ Comments } \\
\hline & & & Axial & Transverse & \\
\hline \multirow[t]{2}{*}{$F C-345$} & SVT-11 & LR324-5 & 16 & 16 & $\begin{array}{l}\text { Large internal grains, } \\
20 \% \text { of thickness }\end{array}$ \\
\hline & & LR324-6 & 16 & 17 & $\begin{array}{l}\text { Large internal grains, } \\
20 \% \text { of thickness }\end{array}$ \\
\hline \multirow[t]{2}{*}{ FC-372 } & SVT-11 & QR820-5 & 16 & 17 & $\begin{array}{l}\text { Large internal grains, } \\
25 \% \text { of thickness }\end{array}$ \\
\hline & & QR820-4 & 19 & 19 & $\begin{array}{l}\text { Large internal grains, } \\
\mathbf{2 5} \% \text { of thickness }\end{array}$ \\
\hline FC-226 & SVT-12 & $\begin{array}{l}\text { P-703-4 } \\
\text { P-703-5 }\end{array}$ & $\begin{array}{r}11 \\
9\end{array}$ & $\begin{array}{l}12 \\
13\end{array}$ & $\begin{array}{l}\text { Uniform microstructure } \\
\text { Uniform microstructure }\end{array}$ \\
\hline \multirow[t]{2}{*}{ FC-628 } & SVT-12 & S-11.1 & 13 & 14 & $\begin{array}{l}\text { Large internal grains, } \\
20 \text { to } 30 \% \text { of thickness }\end{array}$ \\
\hline & & TR-121.2 & 10 & 11 & $\begin{array}{l}\text { Large internal grains, } \\
20 \text { to } 50 \% \text { of thickness }\end{array}$ \\
\hline FC-629 & SVT-12 & $\begin{array}{l}\text { TR-128.1 } \\
\text { TR-127.5 }\end{array}$ & $\begin{array}{l}11 \\
11\end{array}$ & $\begin{array}{l}15 \\
12\end{array}$ & $\begin{array}{l}\text { Uniform microstructure } \\
\text { Uniform microstructure }\end{array}$ \\
\hline FC-604 & SVT-13 & $\begin{array}{l}X-304.1 \\
X-317.5\end{array}$ & $\begin{array}{l}14 \\
13\end{array}$ & $\begin{array}{l}16 \\
16\end{array}$ & $\begin{array}{l}\text { Uniform microstructure } \\
\text { Uniform microstructure }\end{array}$ \\
\hline FC-605 & SVT-13 & $\begin{array}{l}X-317.2 \\
X-317.3\end{array}$ & $\begin{array}{l}12 \\
16\end{array}$ & $\begin{array}{l}15 \\
18\end{array}$ & $\begin{array}{l}\text { Uniform microstructure } \\
\text { Uniform microstructure }\end{array}$ \\
\hline
\end{tabular}

cup portion of the axial breach was particularly interesting, because it occurred in a coarse-grained wall section that contained numerous large voids (Fig. 15). The voids varied in size, with the largest having an apparent diameter of $0.22 \mathrm{~mm}$ (Fig. 16). Although the voids undoubtedly weakened the capsule wall, they did not appear to have been related to the breach. The crack appearance suggested that it initiated on the clad interior, at the boundary of a large grain (Fig. 17), and propagated outward along the grain boundaries.

Examination of the FC-226, FC-228, and FC-62? capsule welds did not reveal any unusual features. All of the welds had acceptable microstructures and were typical of SRP production.

All of the iridium cups were relatively fine grained. The average grain sizes ranged from 8.7 to 14.8 grains/ $0.635-\mathrm{mm}$ nominal wall thickness.

As in previous SVT impacts, the capsule vents were not significantly deformed. No mechanical defects were observed in any of the vents and all of the vent frits were free of deposits. Intergranular attack of the iridium was observed in the FC-226 vent (Fig. 18) and may have also occurred in the FC-628 and FC-629 vents (Figs. 19 and 20). Excessive grain coarsening occurred in wall sections adjacent to asl three vent cover and assembly welds.
Chemical analyses of the SVT-12 iridium clads and ${ }^{238} \mathrm{PuO}_{2}$ fuel pellets did not reveal any anomalies. All components were similar to those used in previous SVT impacts and werc typical of SRP production.

\section{SVT-13}

The test module was impacted against a granite target at $53.4 \mathrm{~m} / \mathrm{s}$ and $975^{\circ} \mathrm{C}$; module orientation was $\alpha=\beta=\gamma=0$. The aeroshell remained integral and sustained unly minor damage (Fig. 21).

The impact shell was moderately damagud, but both GIS caps were retained. Although the amount of overall deformation was minor, the primary GIS was cracked on the impact and trailing faces (Fig. 22). The impact face of the primary GIS contained a wide axial crack, and the trailing face was traversed by a short diagonal crack that apparently originated in the threads of the GIS closure. The secondary GIS was more severely damaged, containing numerous cracks on the impact and lateral faces (Fig. 23). A thin crack was also observed in the closure thread area on the trailing face of the secondary GIS. 


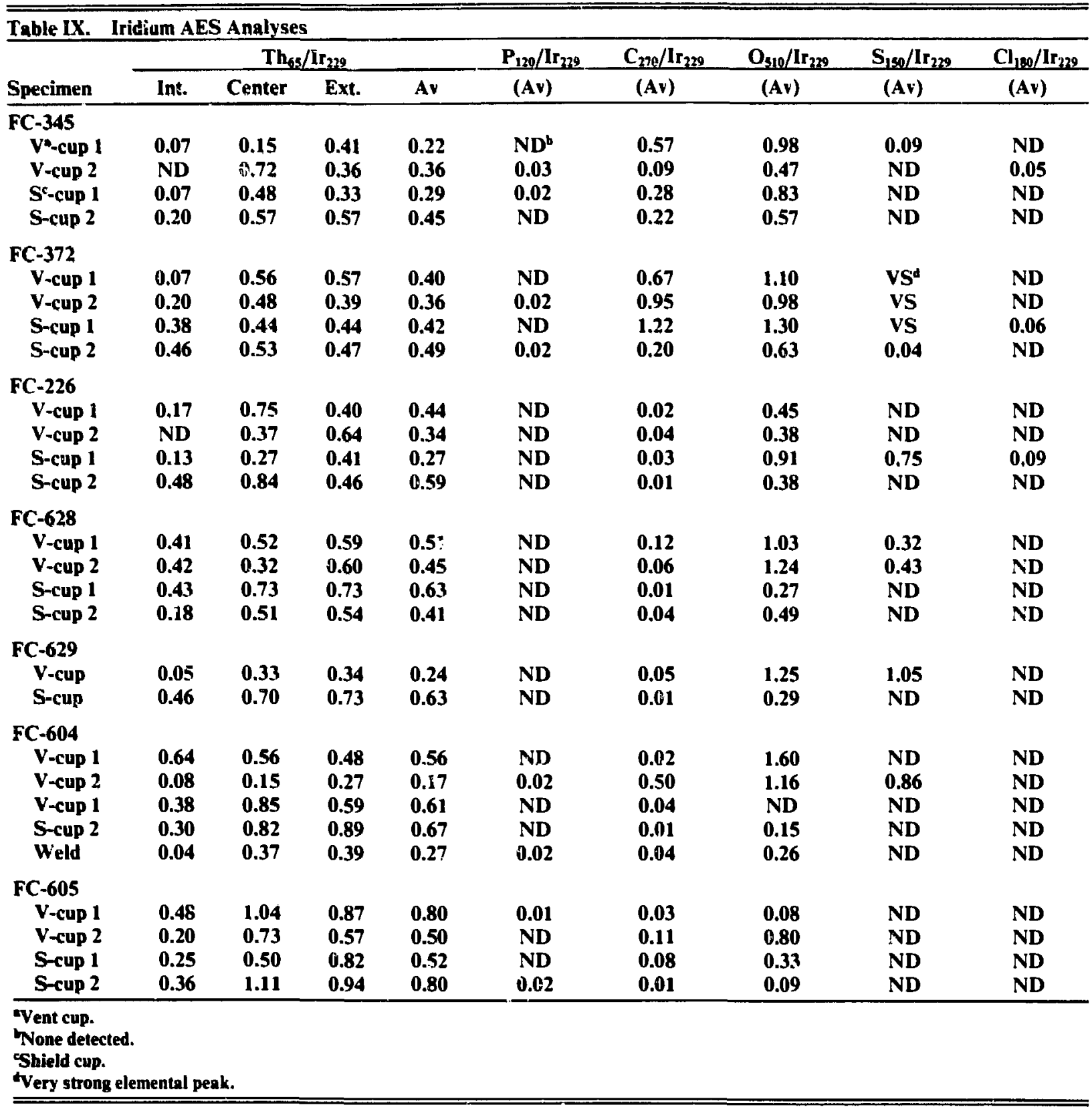




\begin{tabular}{|c|c|c|c|c|c|c|c|c|c|c|}
\hline \multirow[b]{2}{*}{ Capsule } & \multirow[b]{2}{*}{ Cup } & \multicolumn{9}{|c|}{ Selected Elements^ (ppm) } \\
\hline & & $\mathrm{Cu}$ & $\mathbf{M g}$ & $\mathrm{Ca}$ & $\mathbf{A l}$ & $\mathbf{S i}$ & $\mathrm{Cr}$ & $\mathbf{F e}$ & $\mathbf{N i}$ & $\mathbf{P t}$ \\
\hline FC-345 & $\begin{array}{l}\text { LR324-5 } \\
\text { LR324-6 }\end{array}$ & $\begin{array}{l}5 \\
5\end{array}$ & $\begin{array}{l}5 \\
3\end{array}$ & $\begin{array}{l}\text { ND } \\
\text { ND }\end{array}$ & $\begin{array}{l}50 \\
60\end{array}$ & $\begin{array}{l}\text { ND } \\
\text { ND }\end{array}$ & $\begin{array}{l}30 \\
20\end{array}$ & $\begin{array}{l}300 \\
200\end{array}$ & $\begin{array}{l}30 \\
20\end{array}$ & $\begin{array}{l}\text { ND } \\
30\end{array}$ \\
\hline FC-372 & $\begin{array}{l}\text { QR820-5 } \\
\text { QR820-4 }\end{array}$ & $\begin{array}{r}20 \\
5\end{array}$ & $\begin{array}{c}3 \\
\text { ND }\end{array}$ & $\begin{array}{l}\text { ND } \\
\text { ND }\end{array}$ & $\begin{array}{l}60 \\
60\end{array}$ & $\begin{array}{l}20 \\
\text { ND }\end{array}$ & $\begin{array}{l}20 \\
20\end{array}$ & $\begin{array}{l}200 \\
200\end{array}$ & $\begin{array}{l}40 \\
20\end{array}$ & $\begin{array}{l}\text { ND } \\
\text { ND }\end{array}$ \\
\hline FC-226 & $\begin{array}{l}\text { P703-4 } \\
\text { P703-5 }\end{array}$ & $\begin{array}{l}25 \\
25\end{array}$ & $\begin{array}{l}\text { ND } \\
\text { ND }\end{array}$ & $\begin{array}{l}3 \\
3\end{array}$ & $\begin{array}{l}75 \\
7.5\end{array}$ & $\begin{array}{l}\text { ND } \\
10\end{array}$ & $\begin{array}{l}20 \\
30\end{array}$ & $\begin{array}{l}175 \\
200\end{array}$ & $\begin{array}{r}45 \\
100\end{array}$ & $\begin{array}{l}\text { ND } \\
\text { ND }\end{array}$ \\
\hline FC-628 & $\begin{array}{l}\text { S-11.1 } \\
\text { TR-121.2 }\end{array}$ & $\begin{array}{l}15 \\
20\end{array}$ & $\begin{array}{l}\text { ND } \\
\text { ND }\end{array}$ & $\begin{array}{l}\text { ND } \\
\text { ND }\end{array}$ & $\begin{array}{l}70 \\
70\end{array}$ & $\begin{array}{l}15 \\
20\end{array}$ & $\begin{array}{l}50 \\
60\end{array}$ & $\begin{array}{l}350 \\
400\end{array}$ & $\begin{array}{l}100 \\
125\end{array}$ & $\begin{array}{l}\text { ND } \\
\text { ND }\end{array}$ \\
\hline FC-629 & $\begin{array}{c}\text { TR-128.1 } \\
\text { TR-127.5 }\end{array}$ & $\begin{array}{l}20 \\
30\end{array}$ & $\begin{array}{l}5 \\
5\end{array}$ & $\begin{array}{r}8 \\
15\end{array}$ & $\begin{array}{l}70 \\
80\end{array}$ & $\begin{array}{l}20 \\
20\end{array}$ & $\begin{array}{l}\mathbf{5 0} \\
\mathbf{8 0}\end{array}$ & $\begin{array}{l}200 \\
300\end{array}$ & $\begin{array}{l}100 \\
150\end{array}$ & $\begin{array}{l}\text { ND } \\
\text { ND }\end{array}$ \\
\hline FC-604 & $\begin{array}{l}X-304.1 \\
X-317.5\end{array}$ & $\begin{array}{l}30 \\
30\end{array}$ & $\begin{array}{l}15 \\
15\end{array}$ & $\begin{array}{l}20 \\
10\end{array}$ & $\begin{array}{l}80 \\
80\end{array}$ & $\begin{array}{l}\mathbf{5 0} \\
\mathbf{3 0}\end{array}$ & $\begin{array}{l}100 \\
100\end{array}$ & $\begin{array}{l}200 \\
200\end{array}$ & $\begin{array}{l}100 \\
100\end{array}$ & $\begin{array}{l}\text { ND } \\
\text { ND }\end{array}$ \\
\hline FC-605 & $\begin{array}{l}X-317.2 \\
X-317.3\end{array}$ & $\begin{array}{l}30 \\
30\end{array}$ & $\begin{array}{l}\text { ND } \\
\text { ND }\end{array}$ & $\begin{array}{r}3 \\
10\end{array}$ & $\begin{array}{l}50 \\
50\end{array}$ & $\begin{array}{l}20 \\
30\end{array}$ & $\begin{array}{l}50 \\
20\end{array}$ & $\begin{array}{r}100 \\
80\end{array}$ & $\begin{array}{l}40 \\
20\end{array}$ & \\
\hline
\end{tabular}

Elements are listed only if they exceed the detectability limit in at leasi, one specimen.

Wone detected.

\begin{tabular}{|c|c|c|c|c|c|c|c|c|}
\hline \multirow{2}{*}{$\begin{array}{l}\text { Fuel } \\
\text { Pellet }\end{array}$} & \multicolumn{8}{|c|}{ Selected Elements ${ }^{2}$ (ppm) } \\
\hline & $\mathbf{P}$ & $\mathbf{M g}$ & $\mathrm{Ca}$ & Al & $\mathbf{S i}$ & $\mathrm{Fe}$ & $\mathbf{C r}$ & $\mathbf{T i}$ \\
\hline HF-345 & 16 & 2 & 50 & $\mathbf{N D}^{\mathbf{b}}$ & 40 & 85 & ND & $\mathbf{5 0}$ \\
\hline HF-372 & 2 & 8 & 30 & 25 & 20 & 30 & ND & 20 \\
\hline HF-341 & $\mathbf{N D}$ & 5 & 200 & 30 & 20 & 30 & ND & 15 \\
\hline HF-365 & 2 & 10 & 100 & 25 & 30 & 20 & ND & 10 \\
\hline HF-226 & 3 & 10 & 30 & 90 & 10 & 15 & 9 & ND \\
\hline HF-277 & 3 & 10 & 30 & 85 & 8 & 10 & 10 & 7 \\
\hline HF-628 & 3 & 10 & 50 & 100 & 15 & 7 & 20 & 7 \\
\hline HF-629 & 2 & 15 & 100 & 110 & 20 & 25 & 20 & 15 \\
\hline HF-526 & 9 & 1 & 50 & 160 & 5 & 6 & ND & 7 \\
\hline HF-546 & 9 & 5 & 750 & 280 & 35 & 45 & 25 & 10 \\
\hline HF-604 & 10 & 5 & 750 & 145 & 30 & 15 & 30 & 7 \\
\hline HF-605 & 7 & 5 & 100 & 170 & 30 & 20 & 25 & 10 \\
\hline \multicolumn{9}{|c|}{$\begin{array}{l}\text { "Elements are listed only if they exceed detectability limits in at } \\
\text { least one pellet. }\end{array}$} \\
\hline Wone de & to & & & & & & & \\
\hline
\end{tabular}


Capsule deformation was moderate and very homogeneous; no areas of excessive localized deformation were observed on any of the clads. However, capsule FC-604 (a primary clad) was breached by a smali centerline weld crack located $90^{\circ}$ from the impact face (Fig. 24). Subsequent analysis of the SVT-13 graphitics and catch tube debris revealed that a total of $0.0183 \mathrm{~g}$ of plutonium had been released through the breach and by transport through the capsule vents.

Metallographic examination of sections from the FC-604 capsule wcld revealed that the failure was related to the poor quality of the weld. The weld microstructure near the center of the breaching crack was extremely coarse (Fig. 25), and it may have contained only 1 grain/thickness at the initial point of failure. A second weld specimen contained a large void (approximately $0.2 \mathrm{~mm}$ in diameter) at the edge of the weld fusion zone (Fig. 26). This weld had an SRP/NDE rating of 2.3.

The FC-605 closure weld had an acceptable microstructure and contained no observable defects.

Metallographic examination of wall sections removed from the FC-604 and FC-605 iridium cups revealed generally fine grained rnicrostructures, with isolated areas of anomalous grain growth; the cup grain sizes ranged from 11.9 to 17.6 grains $/ 0.635-\mathrm{mm}$ nominal wall thickness. A network of deep cracks that occurred in a defornied section of the FC-604 vent cup (Fig. 27) was directly related to the coarse microstructure. The cracks initiated between coarse iridium grains and followed the grain boundaries to within $0.36 \mathrm{~mm}$ of the cup exterior. Small intergranular cracks, unrelated to grain growth, were also observed in the FC-605 weld shield cup (Fig. 28). The largest of these cracks penetrated less than $40 \%$ of the total wall thickness (Fig. 29).

Because the fuel capsules were only moderately deformed, the capsule vents were relatively undamaged. Metallographic examination revealed that the FC-604 and FC-605 vents were free of mechanical defects and contained no intermetallic depusits or fuel fragments. Significant grain coarsening did occur, however, on one side of the FC-604 vent cover and assembly welds (Fig. $30)$. The FC-605 welds were free of the grain growth usually observed at these locations.

Spectrographic and AES analyses of the SVT-13 primary clads indicated that they were chemically similar to one another and to clads tested in previous SVT impacts. Although significant thorium depletion was detected on the FC-604 vent and weld shield cup interiors, no microstructural anomalies were observed that could be correlated with the reduced thorium contents.

Ceramographic examination of samples from the SVT-13 fuel pellets revealed typical plutonia microstructures. Chemical analyses of the pellets indicated that they were similar to one another and to the pellets used in previous SVT impacts.

\section{DISCUSSION}

The results of the three impact tests indicate that in terms of capsule and graphite component damage, concrete is a more benign impact surface than steel. The average SVT-11 capsule was less deformed than capsules in the first four SVT impacts, which used the same module impact orientation against steel targets. Even the SVT- 12 clad deformations (impact velocity = $75.5 \mathrm{~m} / \mathrm{s}$ ) were not significantly different from the deformations produced in the first four SVT impacts (average impact velocity $=54.5 \mathrm{~m} / \mathrm{s}$ ). Impact against a granite surface produces capsule deformations that are more severe than those of capsules impacted against concrete but less severe than those of capsules impacted against steel (given equivalent impact oricntations and velocities).

In SVT-I I, the clad deformations were moderate and generally symmetrical. Although one of the primary clads (FC-345) contained two areas of severe loc $x$ lized iridium deformation resulting from fuel fragment displacement, no failures occurred in this or any of the other capsules.

The SVT-12 clad deformations were surprisingly moderate considering the high impact velocity. Although two of the SVT-12 capsules breached, the total crack area was only $17.0 \mathrm{~mm}^{2}$, and the fuel release was actually less than in three previous SVT impacts (SVT-1, SVT-7, and SVT-8) against steel. The cracks in the breached primary clad (FC-628) were exclusively intergranu!ar and apparently resulted from the differential displacement of large fuel fragments. The breached secondary clac (FC-226) cracked on the trailing face; the crack apparently resulted from simple stress overload produced by deformation.

Capsule deformation in SVT-13 was moderate and very homogeneous; no areas of localized iridium deformation were obsarved on any of the clads. However, one primary capsule (FC-604) was breached by a small centerline weld crack. The failure was directly related to the poor weld quality. Metallographic examination revealed that the weld was extremely coarse grairied and that it contained a large void.

Results of chemical and microstructural analyses indicate that the iridium cups used in SVT-11 through SVT-13 were similar to those used in previous SVT impacts. The cup microstructures were generally fine grained; the average grain sizes ranged from 9 to 19 grains/0.635-mm nominal wall thickness.

Although AES analysis revealed thorium depletion on the interior of many cups, no anomalies that could be 
correlated with the low thorium contents were observed in any of the cup microstructures. Similarly, detectable levels of phosphorus, sulfur, and chlorine were observed in several cups, but the amounts of these elements apparently had no effect on the capsule responses.

Abnormal grain growth in wall sections adjacent to the vent cover and assembly welds was observed in most of the capsule vents examined (Fig. 6 and 30). Gran coarsening at this location has been observed in nearly all of the clads examined from previous tests. Such grain growth at the same location in so many capsules suggests a relation to sume aspect of the production process. Whatever the cause, grain coarsening adjacent to the capsule vent increases the probability of a breach in any impact that significantly deforms the vent assembly.

Although all or the vents examined were relativeiy undeformed and free of deposits, indications of intergranular attack of the iridium were observed in three SVT-12 capsule vents (Figs. 18, 19, and 20). We were unable to identify the mechanism responsible for this degradation.

Spectrographic and radiochernical anaiyses of the fue! pellets indicated that they were sirnilar to the pellets used in previous SVT impacts. All of the pellets fractured in a brittie manner. The pellet microstruciures were typical of SRP fuel.

\section{CONCLUSIONS}

(1) Concrete is a more benign impact medium than steel. The capsule deformations in SVT-1I were significantly less than those observed in similarly oriented impacts against steel. Even the SVT-12 clad deformations (impact velocity $75.5=\mathrm{m} / \mathrm{s}$ ) were not significantly different from those observed in the first four SVT impacts (average velocity = $54.5 \mathrm{~m} / \mathrm{s}$ ).

(2) Impact against granite produces clad de irmations more severe than those of capsules impacted against concrete, but less severe than those of capsules impacted against steel.

(3) The differential displacement and subsequent pushthrough of large fuel fragments caused the failure of one SVT-12 primary clad (FC-628).

(4) Extensive fuel breakup caused the failure of one SVT-12 secondary clad (FC-226). The impact apparently fragmented the fuel into small fragments, which permitted excessive clad deformation and forced the trailing face of the capsule to stretch. The failure occurred as a result of the simple stress overload.
(5) The failure of one primary clad in SVT-13 (FC-604) was directly related to the poor quality of the capsule weld. The weld had an extremely coarse microstructure and contained a large void.

(6) The failure of the FC-604 weid (NDE value 2.3) demonstrates the limitations of the ultrasonic technique currently used to determine weld quality. The technique provides no information about microstructure and apparently ignores spherical defects such as voids.

(7) Large grains were observed adjacent to nearly all of the vent assembly and decontamination cover welds examined. Such unusual grain coarsening at the same location in so many clads suggests a relation to some aspect of the production process.

(8) AES analyses revealed significant thorium depletion on the interiors of several iridium cups. However, none of the microstructurat anomalies observed in the Auger specimens could be correlated with the reduced thorium contents.

(9) Chemical and metallographic analyses of the iridium cups and plutonia fuel pellets revealed that they were typical and reniesentative of flight-quality components.

\section{ACKNOWLEDGMENTS}

We thank the following for their valuable assistance in completing these tests: C. Frantz, M. Anstey, and A. Herrera for impact testing; J. Archuleta and L. Bergamo for metallography; D. Garinger for sieve analysis; and Los Alamos Group WX-3 for radiography.

\section{REFERENCES}

1. "Updated Safety Report for the Galileo Mission and the International Solar-Polar Mission," General Electric Co. document GESP-7186, Sec. 3.4 (GPHS Reentry Response) (April 1984).

2. "GPHS Safety Verification Test Series Procedurc Manual," Los Alamos National Laboratory document MST-5-C-83-19, Sec. 1.0 (April 14, 1983).

3. T. G. George and F. W. Schonfeld, "GeneralPurpose Heat Source Development: Safety Test Program, Postimpact Evaluation, Design Iteration Test 5," Los Alamos National Laboratory report LA-10232-SR (December 1984). 
4. D. Pavone, T. G. George, and C. E. Frantz, "General-Purpose Heat Source Safety Verification Test Series: SVT-1 Through SVT-6," Los Alamos National Laboratory report LA-10353-MS (June 1985).

5. T. G. George and D. Pavone, "General-Purpose Heat Source Safety Verification Test Series: SVT-7
Through SVT-10," Los Alamos National Laboratory report LA-10408-MS (September 1985).

6. "Estimat ss for the Orbital Lifetimes for Galileo and Solar-Polar," Applied Physics Laboratory document ATD-RL-82-081/ANSP-L-662 (November 18, 1982).

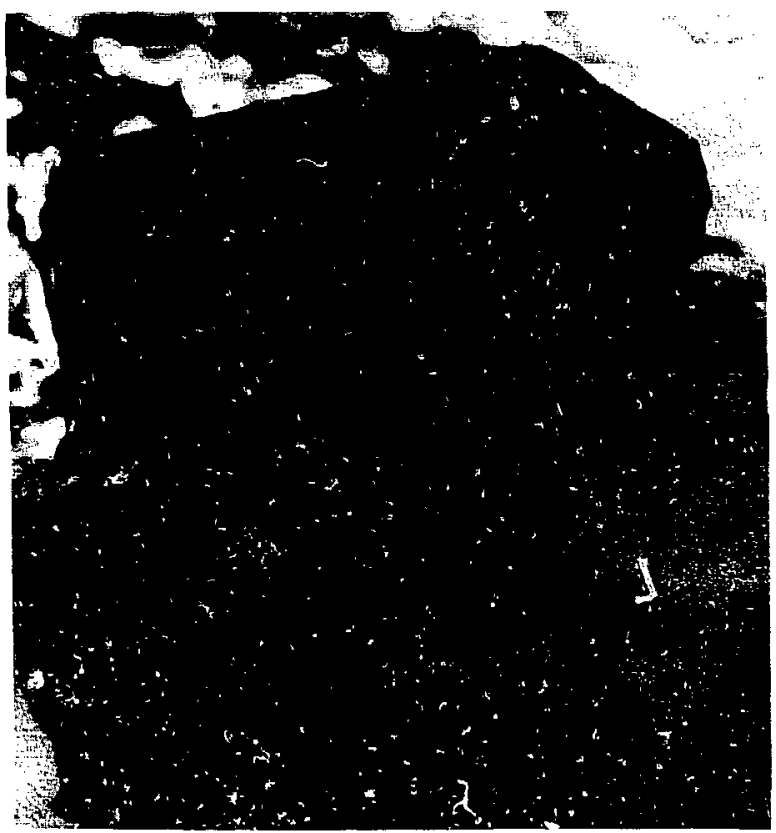

(a)

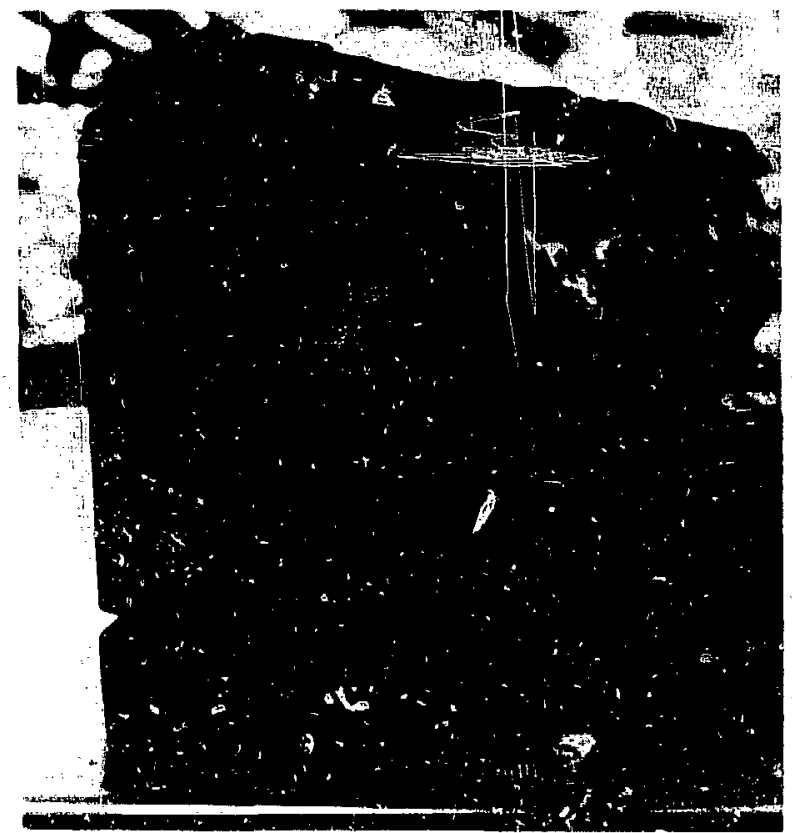

(b)

Fig. 3. Damage to the SVT-11 aeroshell was less than in sirnilar impacts against steel targets. (a) Impact face and (b) trailing face. 


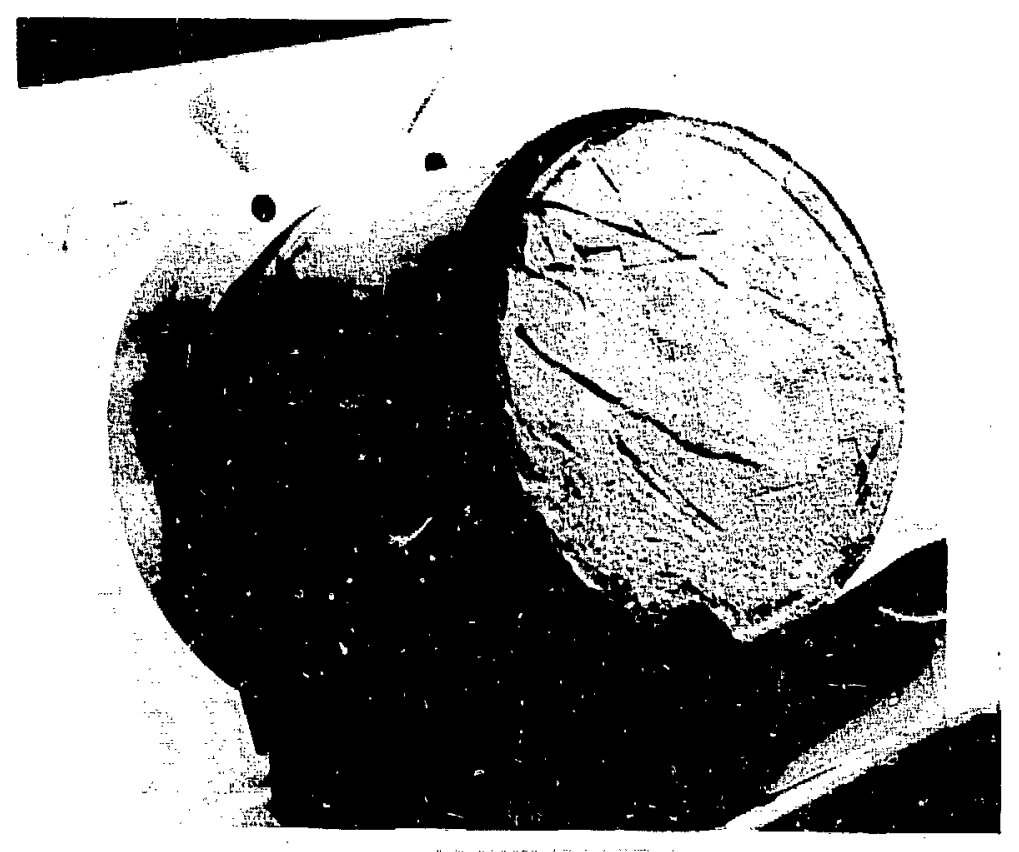

Fig. 4. An imprint of the SVT-11 aeroshell was visible on the face of the concrete target; $0.3 \mathrm{X}$.
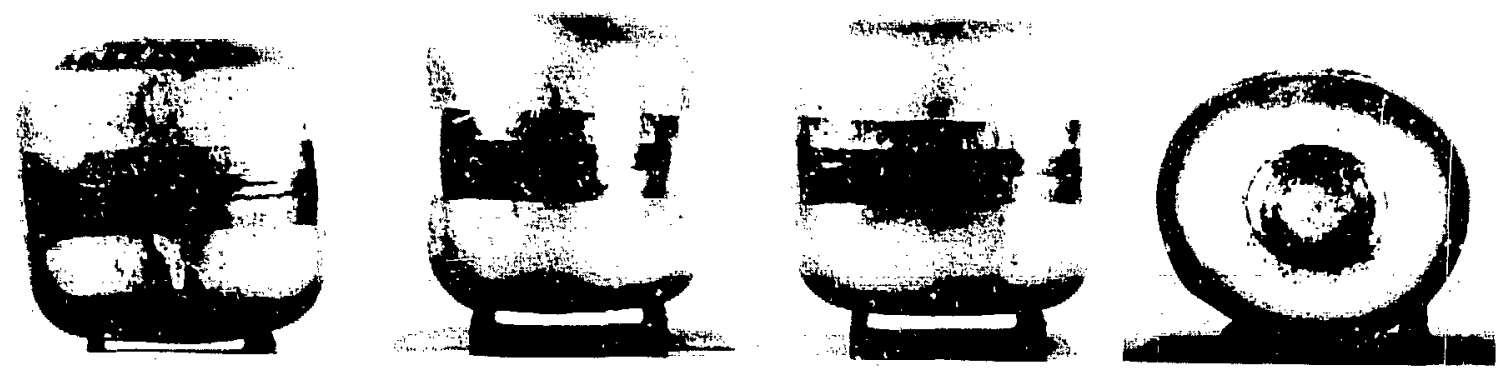

Fig. 5. The appearance of capsule FC-345 was typical of the SVT-11 clads. From left to right-impact face, profile, trailing face, and vent end; all at $1.1 \mathrm{X}$. 


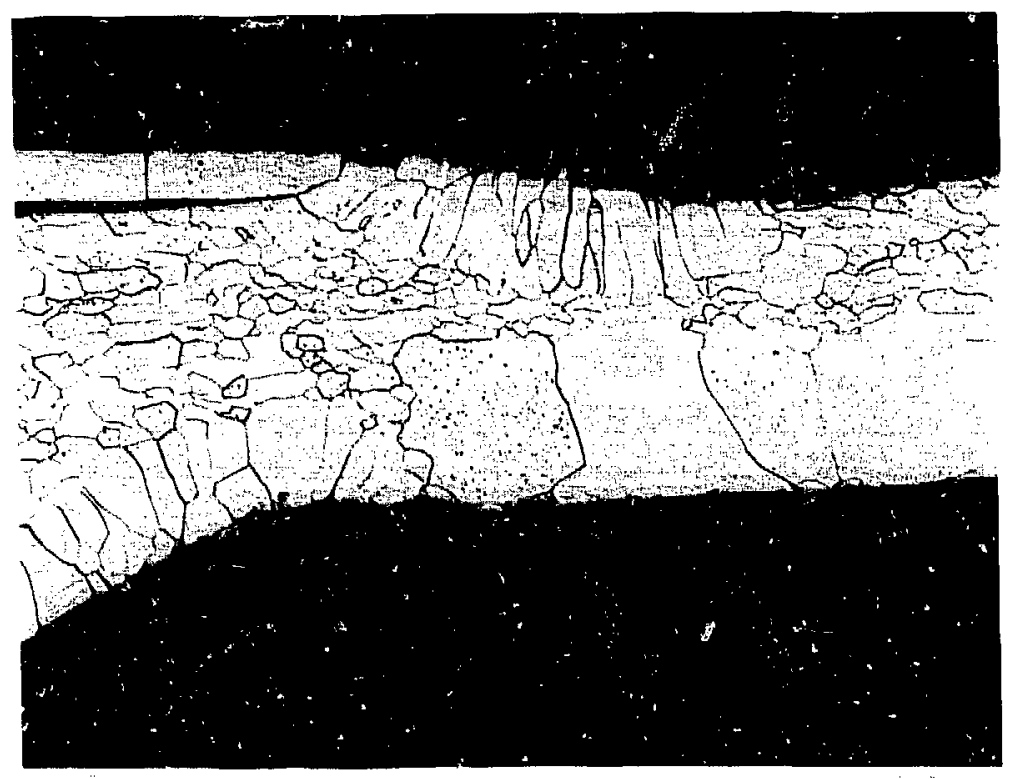

(a)

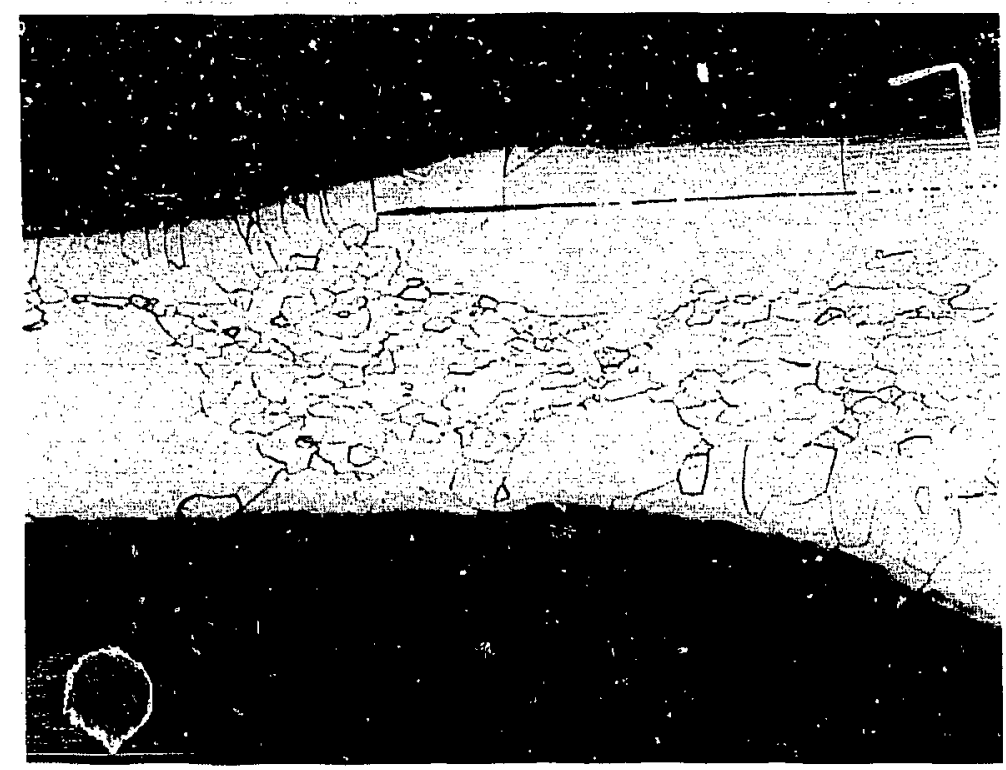

(b)

Fig. 6. Abnormally large iridium grains were observed adjacent to the FC-345 and FC-372 vent cover welds. (a) The FC-345 weld and (b) the FC-372 weld; both at $50 \mathrm{X}$. 


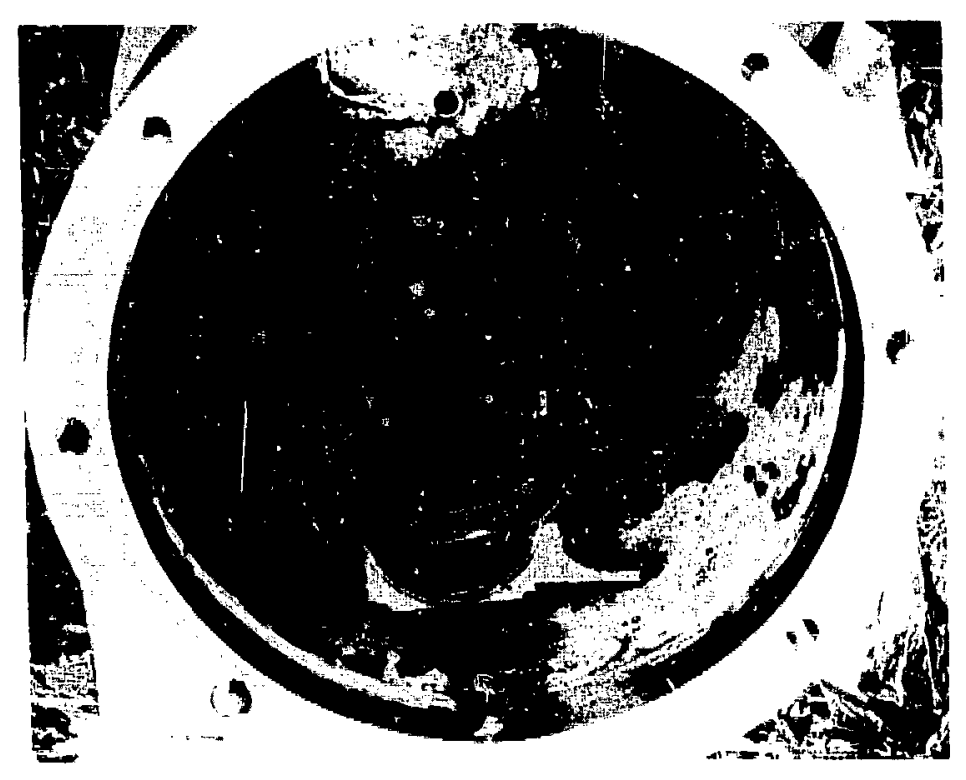

Fig. 7. The SVT-12 aeroshell was destroyed by the impact.

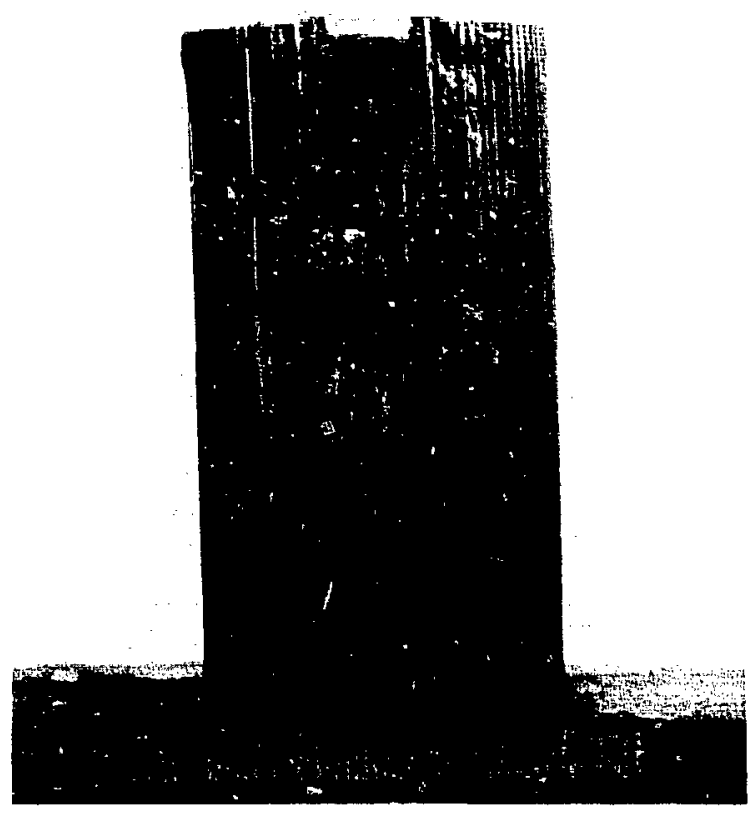

(a)

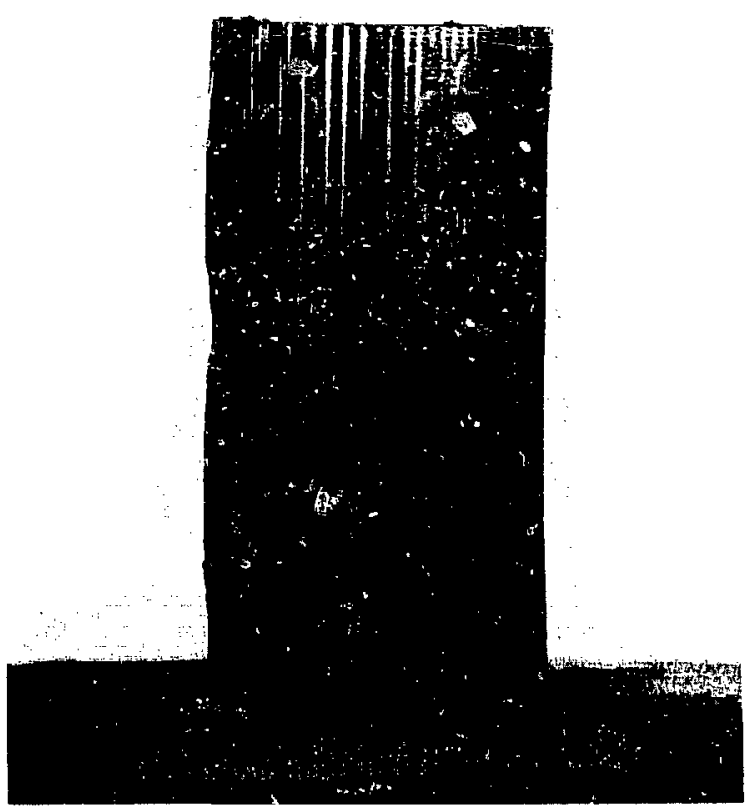

(b)

Fig. 8. The impact of the primary GIS contained a network of axial cracks that ran the GIS length. (a) Impact face and (b) profile; both at 1.0X. 


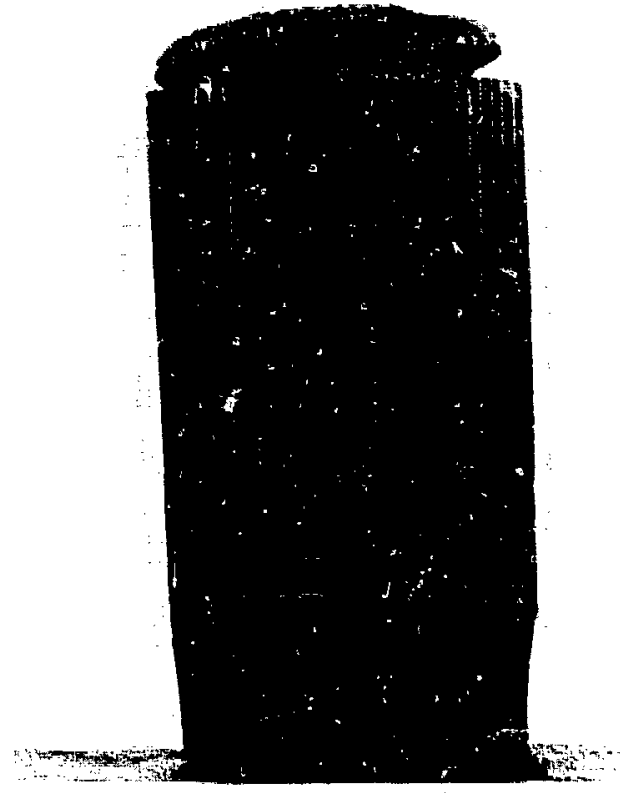

(a)

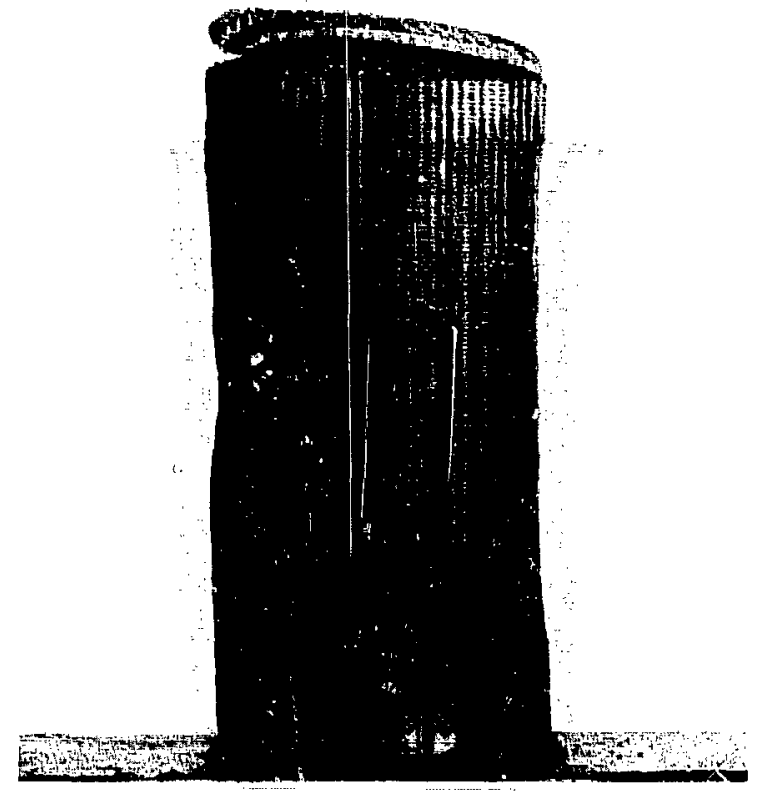

(b)

Fig. 9. The secondary GIS contained a wide axial crack on the impact face. (a) Impact face and (b) profile; both at 1.0X.

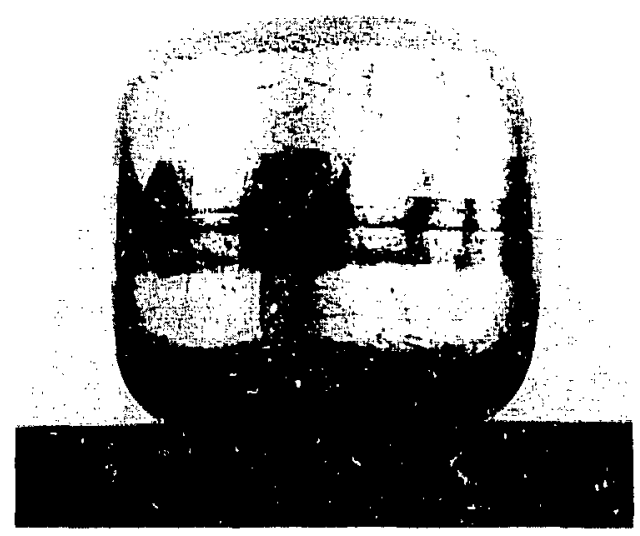

Fig. 10. The impact face of capsule FC-628 was breached by two small cracks; $1.5 \mathrm{X}$. 


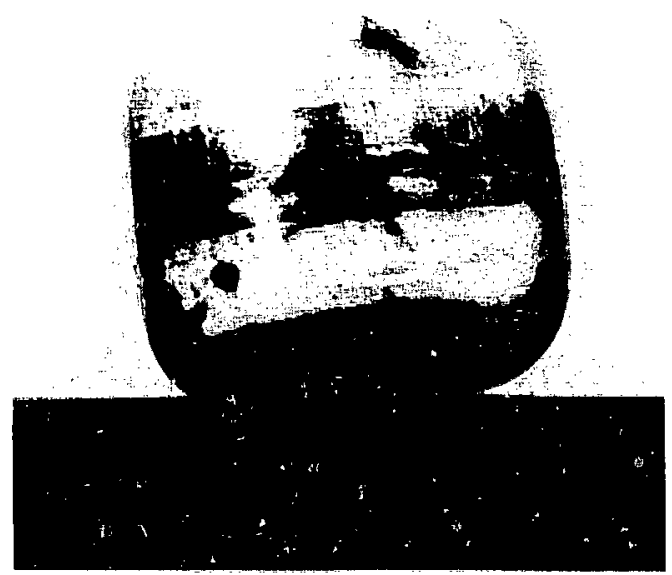

(a)

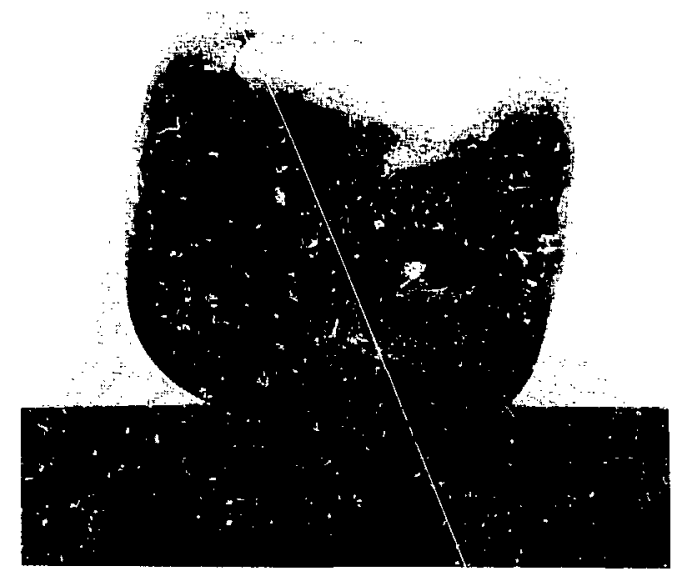

(c)

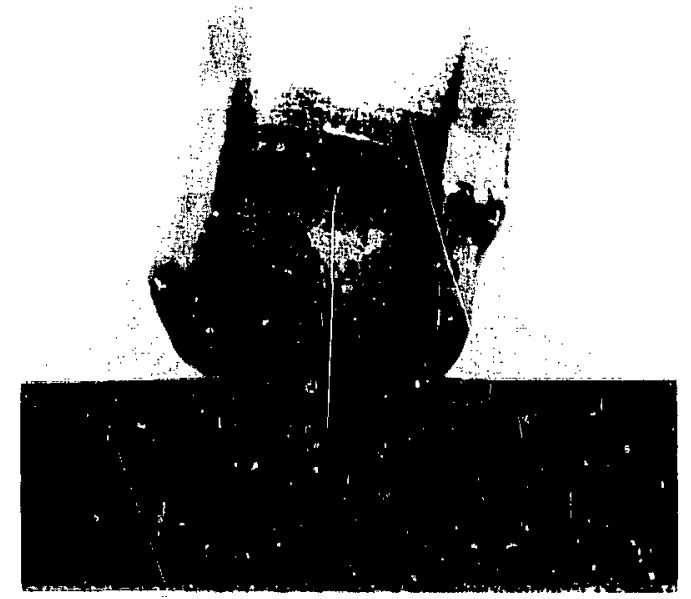

(b)

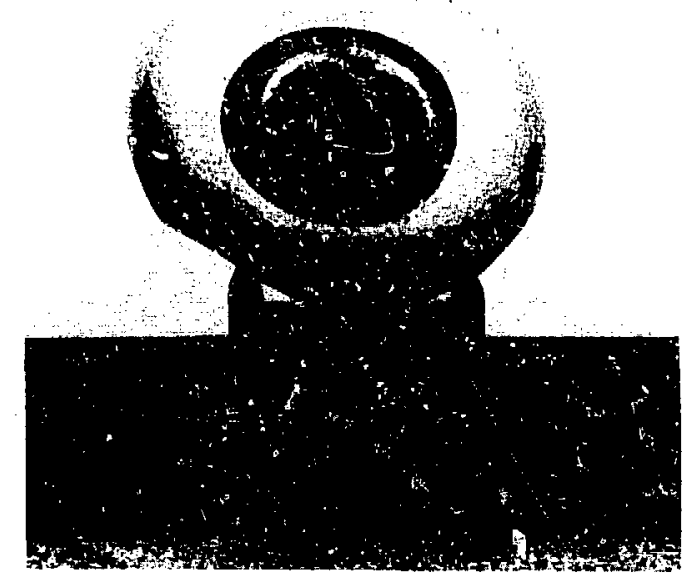

(d)

Fig. 11. Capsule FC-226 was severely deformed and breached on the trailing face. (a) Impact face, (b) profile, (c) trailing face, and (d) vent end; all at $1.5 \mathrm{X}$. 


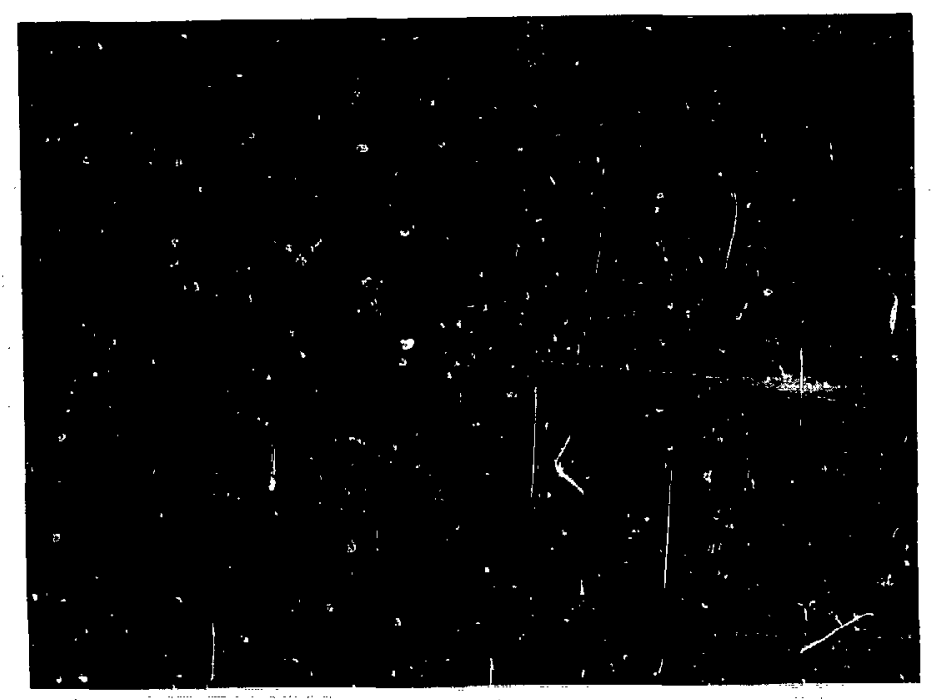

(a)

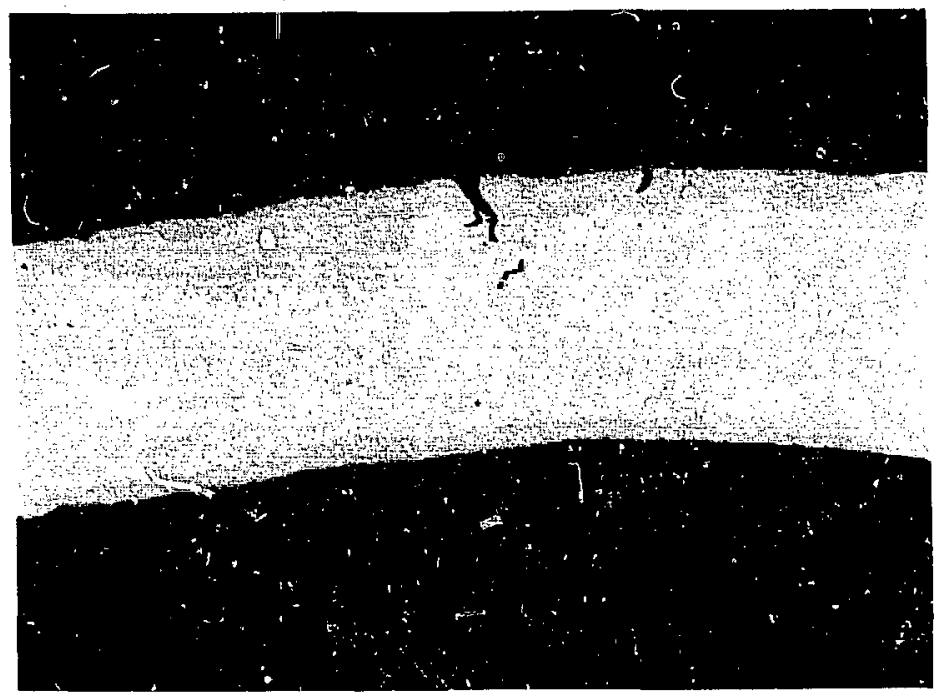

(b)

Fig. 12. Several shallow surface cracks were observed adjacent to the FC-2.26 breach. (a) $7 \mathrm{X}$ and (b) 50X; both as polished. 


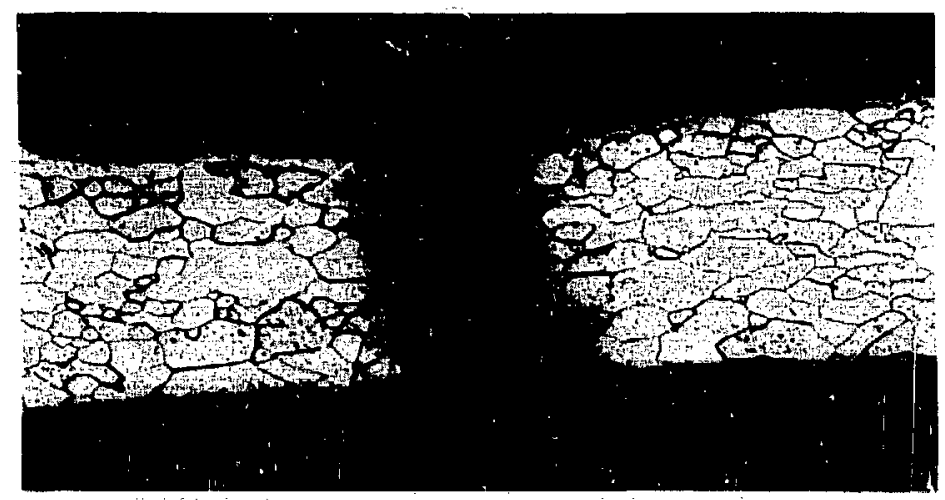

Fig. 13. The FC-226 breach was exclusively intergranular. Vent cup, 50X.

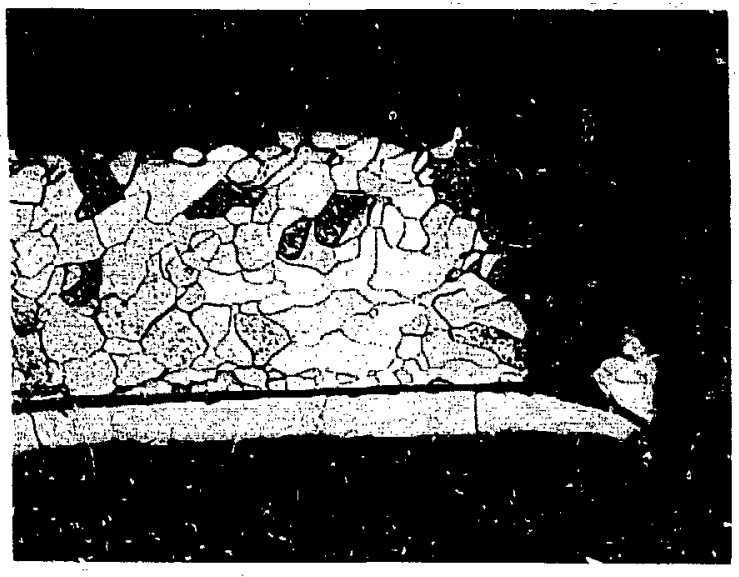

(a)

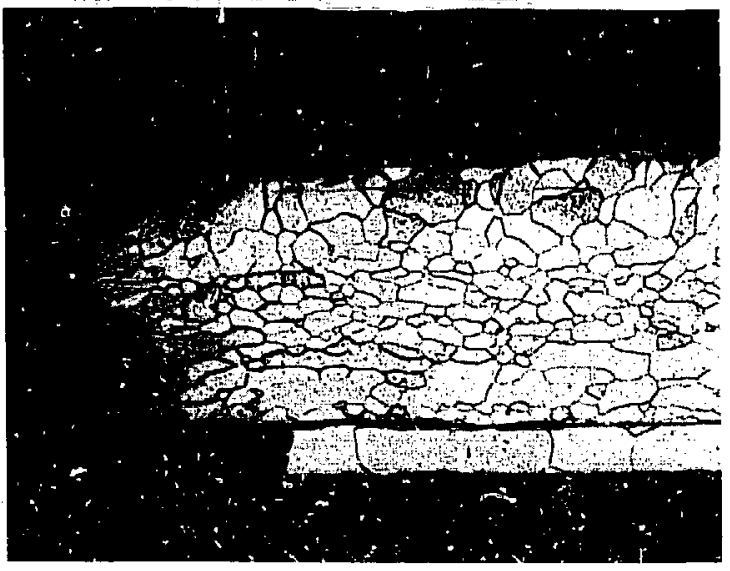

(b)

Fig. 14. Slight grain elongation was observed in shieid cup sections adjacent to the FC-226 breach; (a) and (b), both etched and at 50X. 


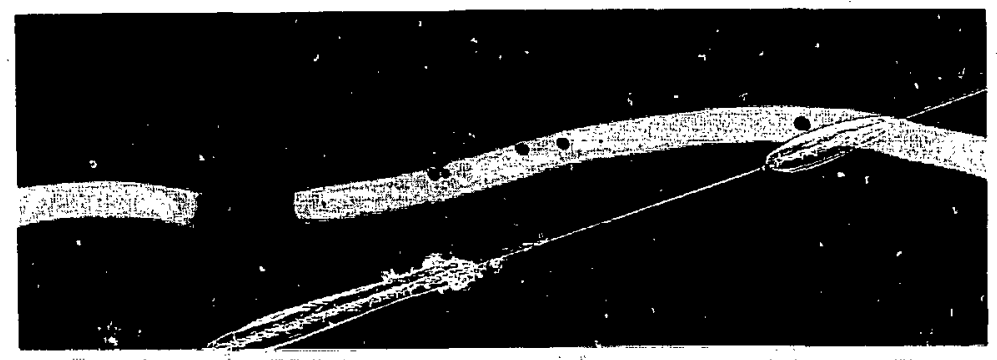

Fig. 15. Numerous large voids were observed in a shield cup section adjacent to the FC- 628 axial breach; as polished, $6.5 \mathrm{X}$.

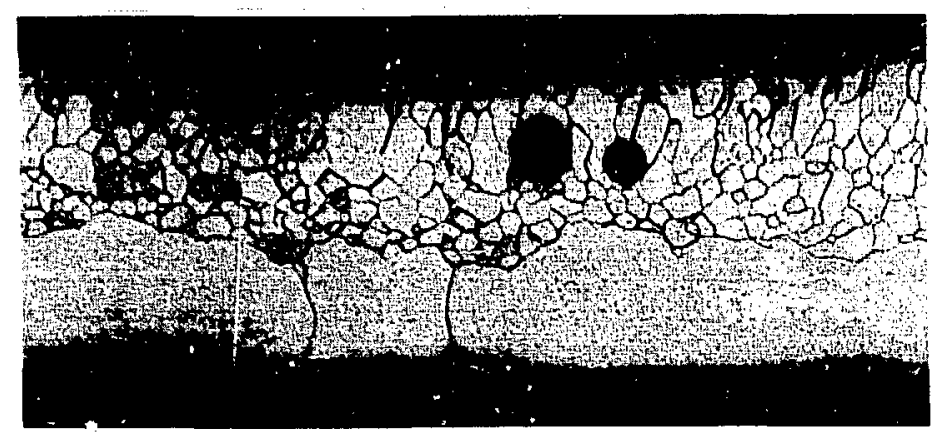

(a)

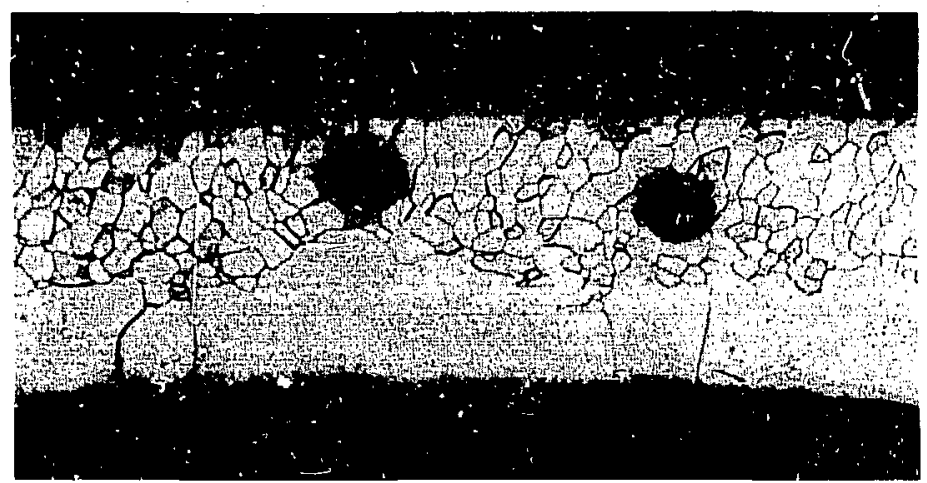

(b)

Fig. 16. Voids in the FC-628 shield cup section may have been related to the grain coarsening; (a) and (b), both etched and at $50 \mathrm{X}$. 


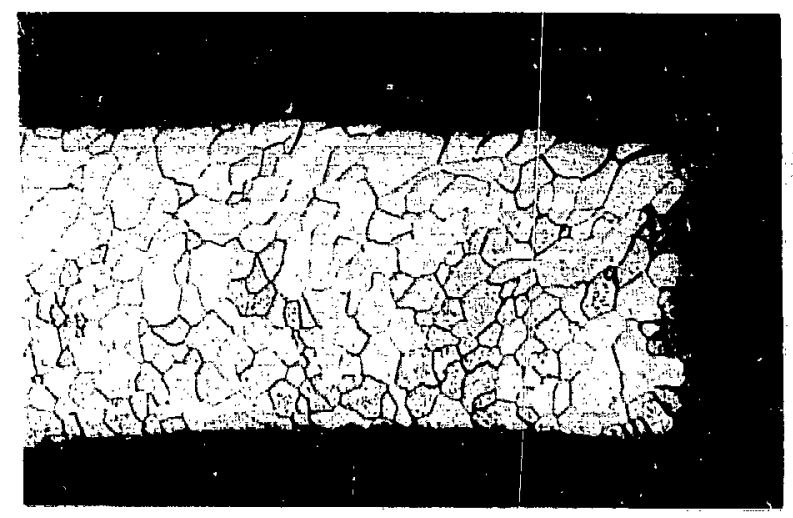

(a)

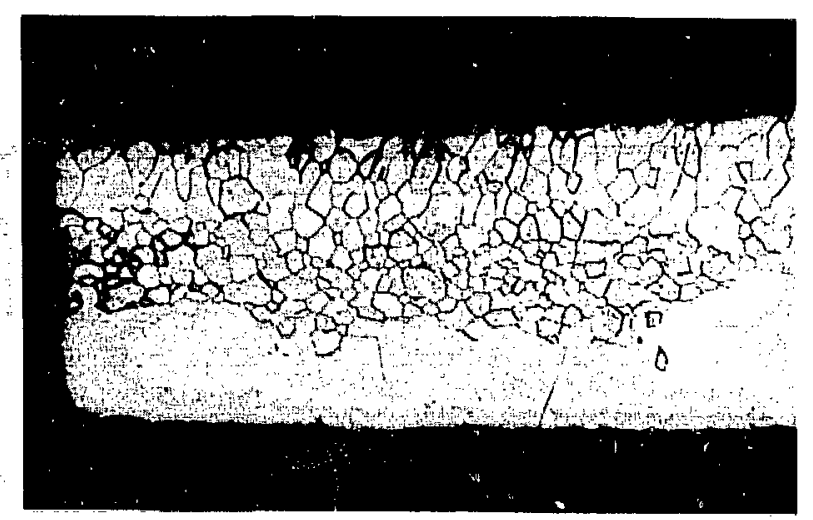

(b)

Fig. 17. The FC-628 axial breach was exclusively intergranular; (a) and (b; both etched and at $50 \mathrm{X}$.

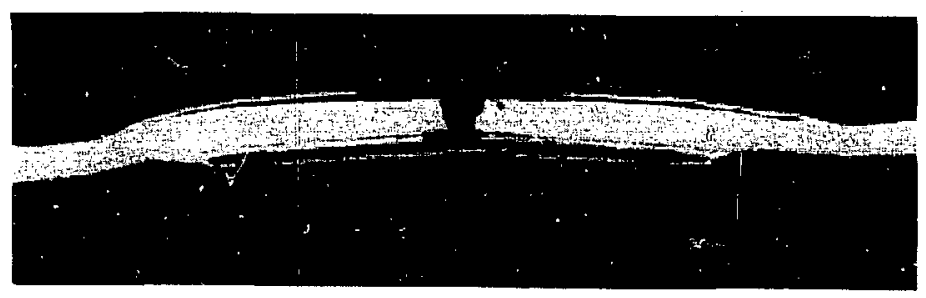

Fig. 18. Intergranular attack was observed on the FC-226 vent; as polished, ?X. 


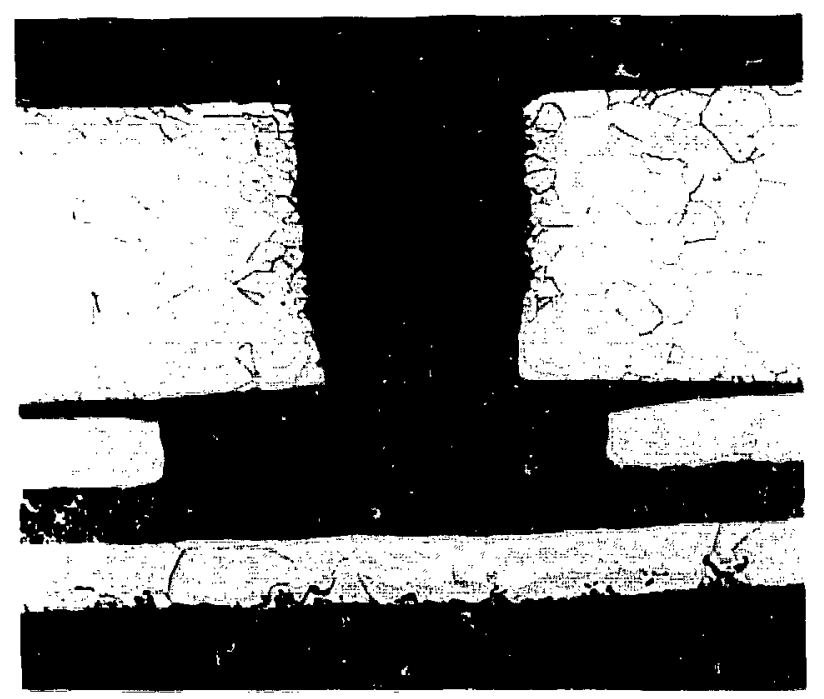

Fig. 19. There was also evidence of intergranular attack in the throat of the FC-628 vent; SOX.

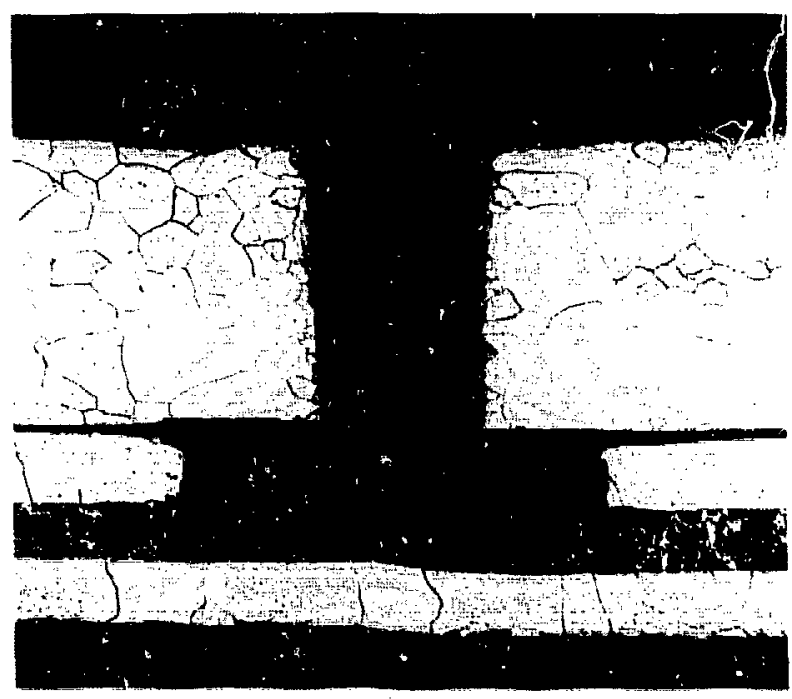

Fig. 20. The iridium in the FC-629 vent also appeared to have been intergranularly attacked; $50 \mathrm{X}$.

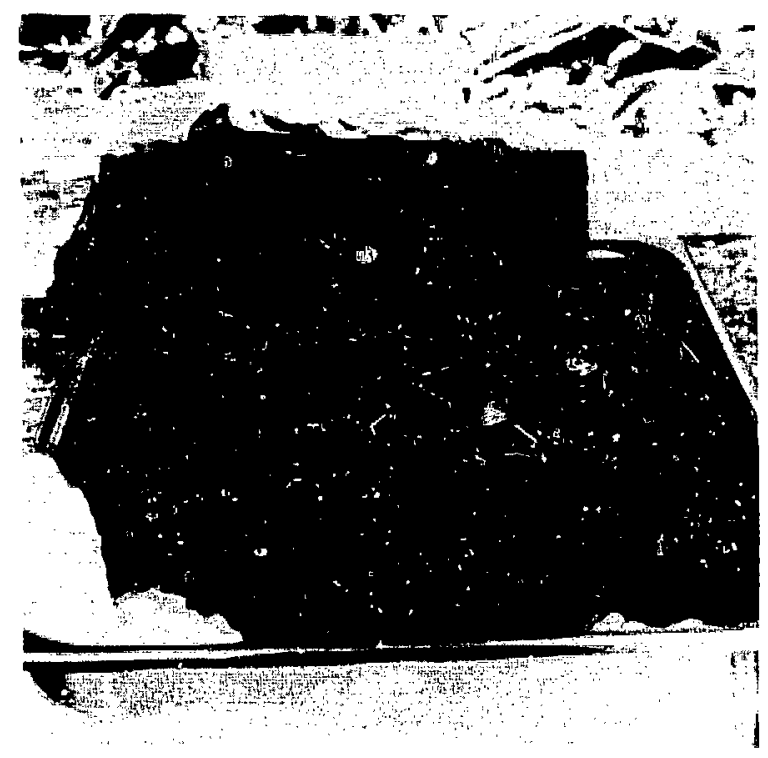

Fig- 21. The SVT-13 aeroshell sustained only minor damage. 


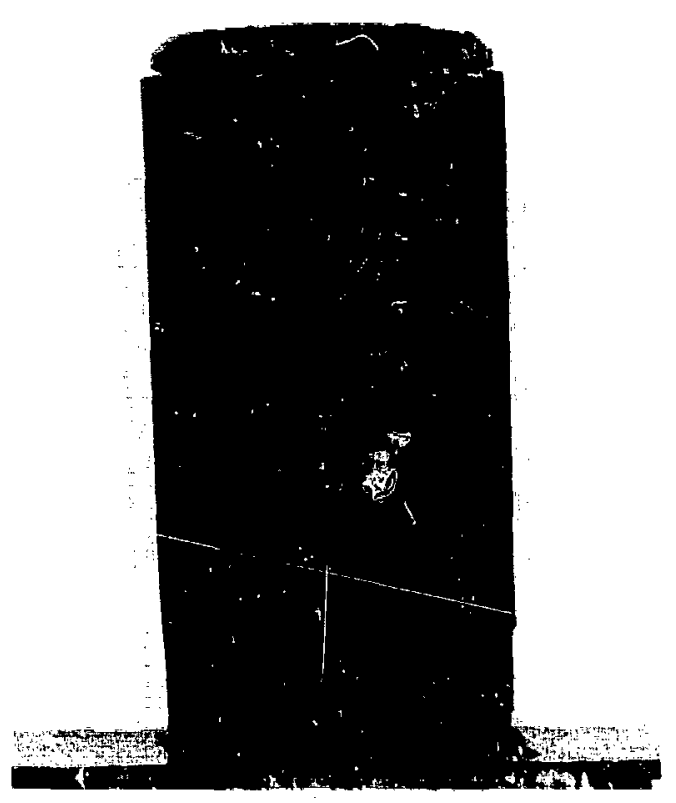

(a)

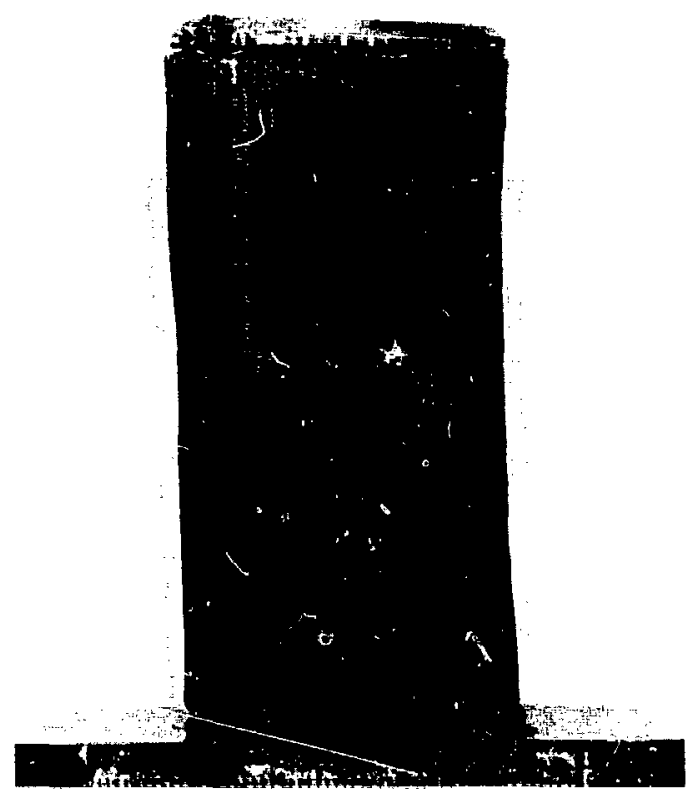

(b)

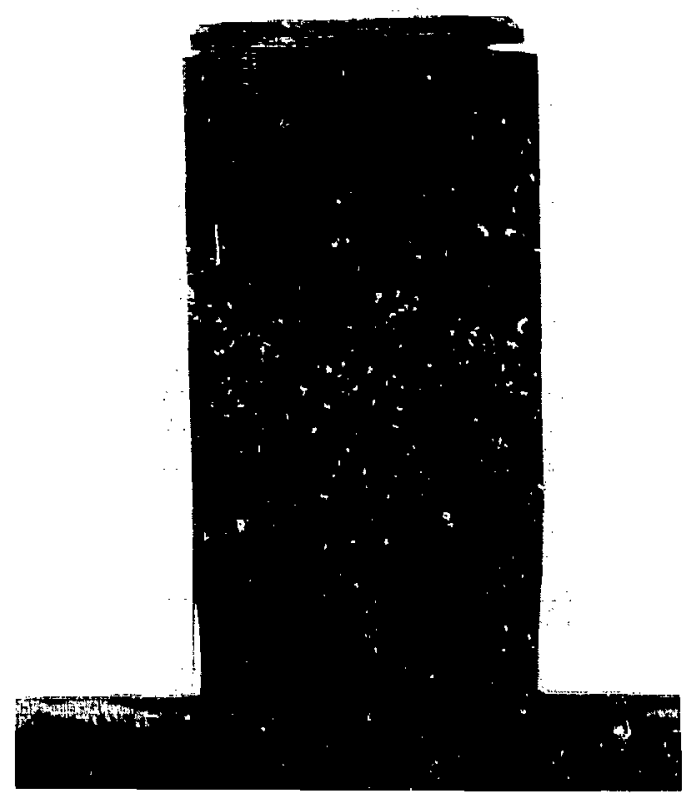

(c)

Fig. 22. The primary GIS cracked on the impact and trailing faces. (a) Impact face, (b) profile, and (c), trailing face; all ai $1.0 \mathrm{X}$. 


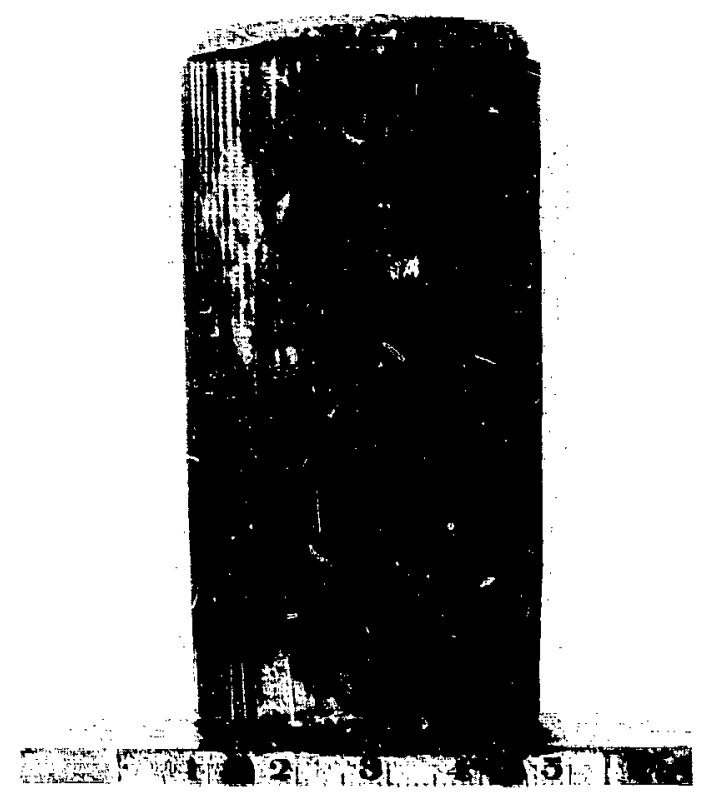

(a)

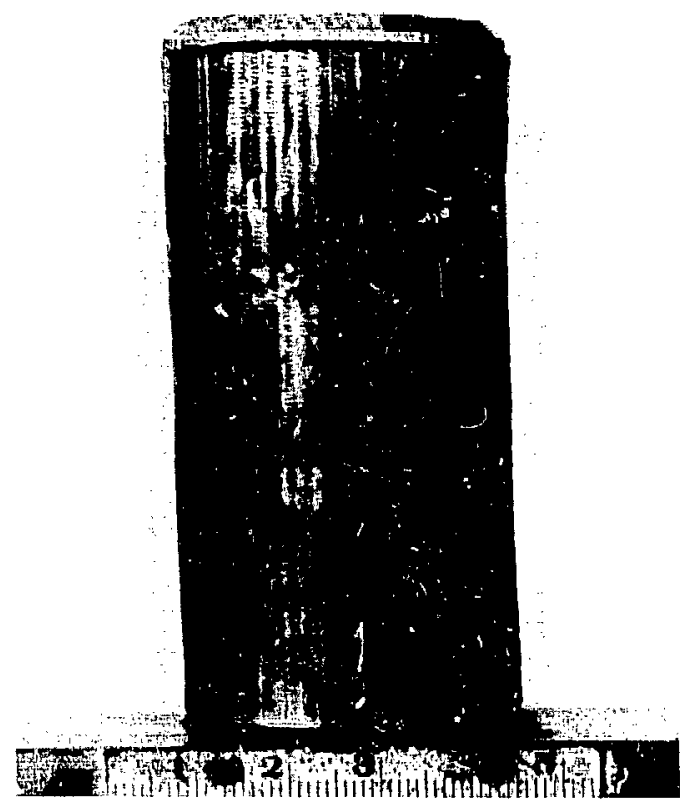

(b)

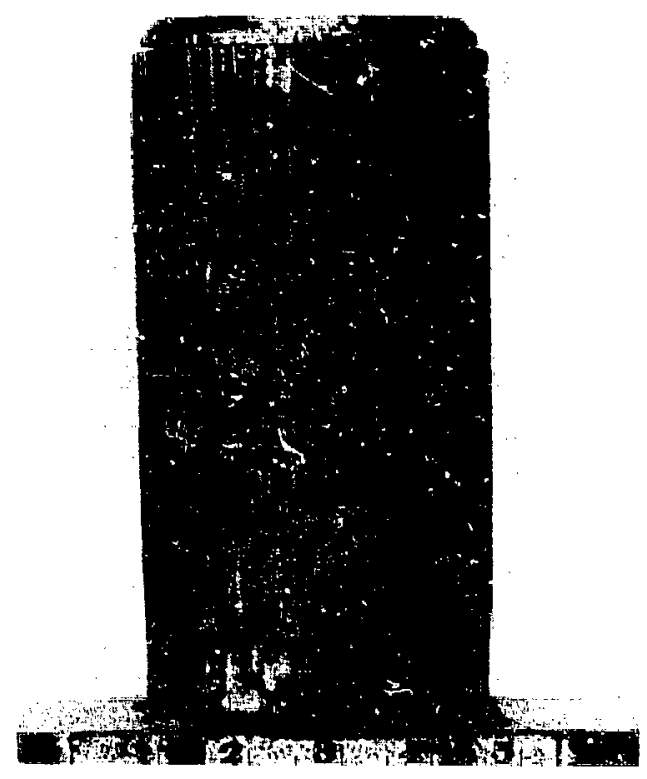

$(r)$

Fig. 23. The secondary GIS contained numerous cracks on the impact and lateral faces. (a) Impact face, (b) profile, and (c) trailing face; all at $1.0 \mathrm{X}$. 


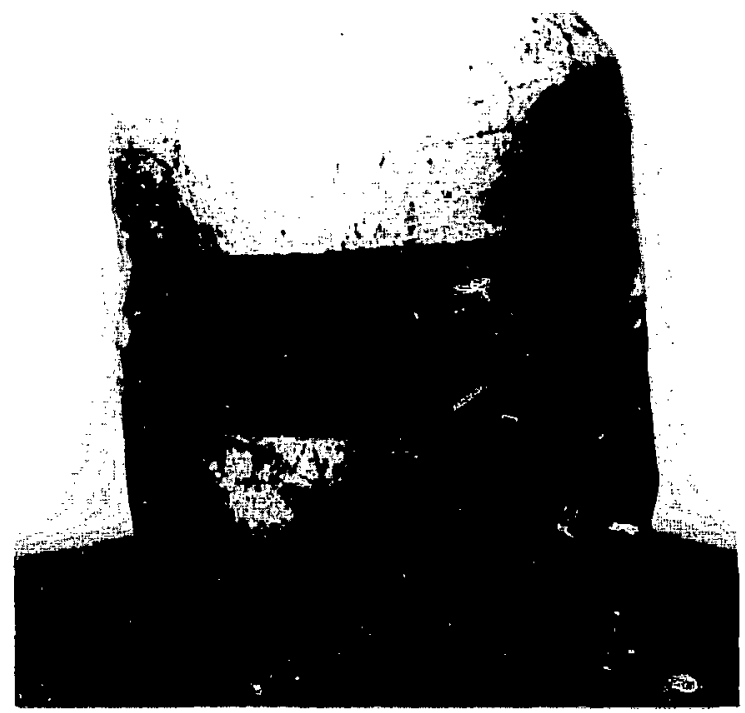

Fig. 24. Capsule FC-604 was breached by a small centerline weld crack located $90^{\circ}$ from the impact face; $2 X$.

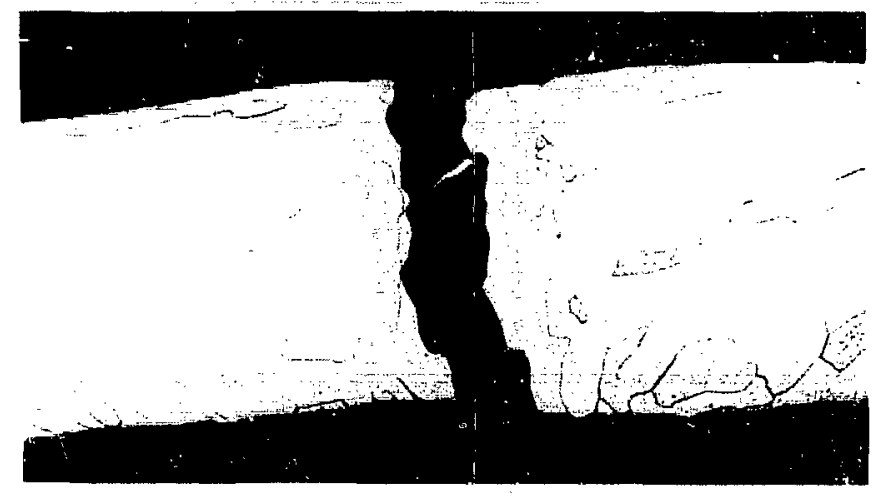

Fig. 25. The weld microstructure near the center of the breaching crack was extremely coarse; $50 \mathrm{X}$. 

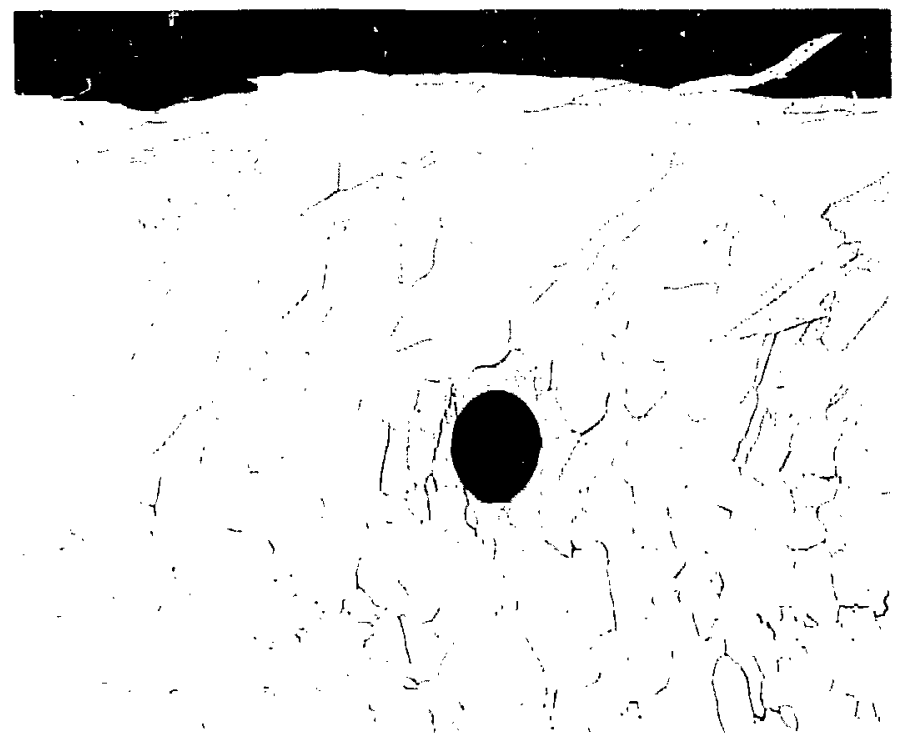

Fig. 26. Another FC-604 weld specimen contained a large void; $100 \mathrm{X}$.

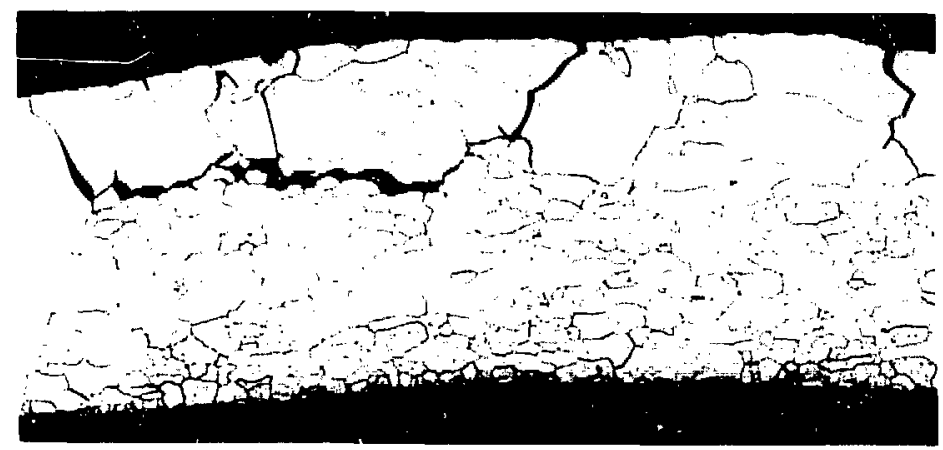

Fig. 27. A network of deep cracks was observed in a deformed section of the FC-604 vent cup; 50X. 


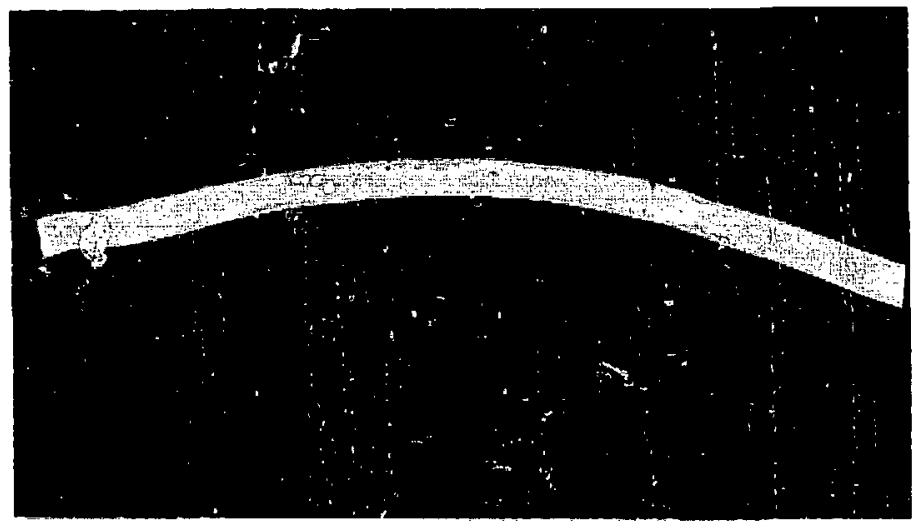

Fig. 28. Small intergranular cracks were also observed in a section of the FC-605 shield cidp; $7 \mathrm{X}$.

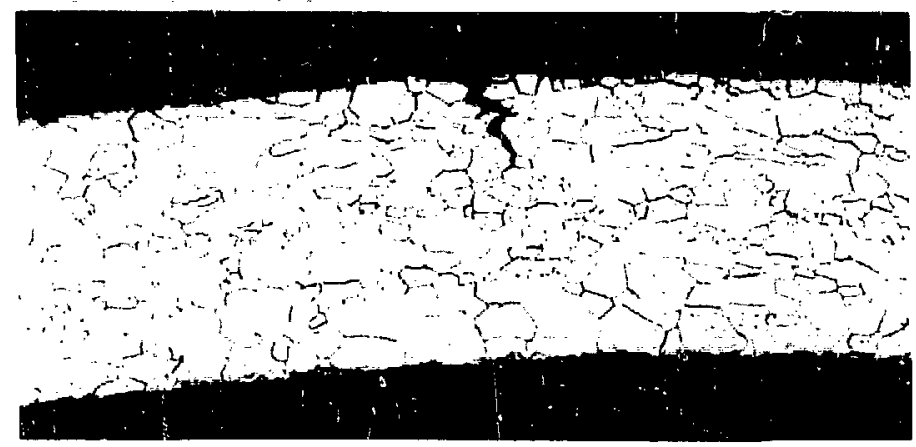

Fig. 29. The largest crack in the FC-605 shield cup penetrated less than $40 \%$ of the total wall thickness; $50 \mathrm{X}$.

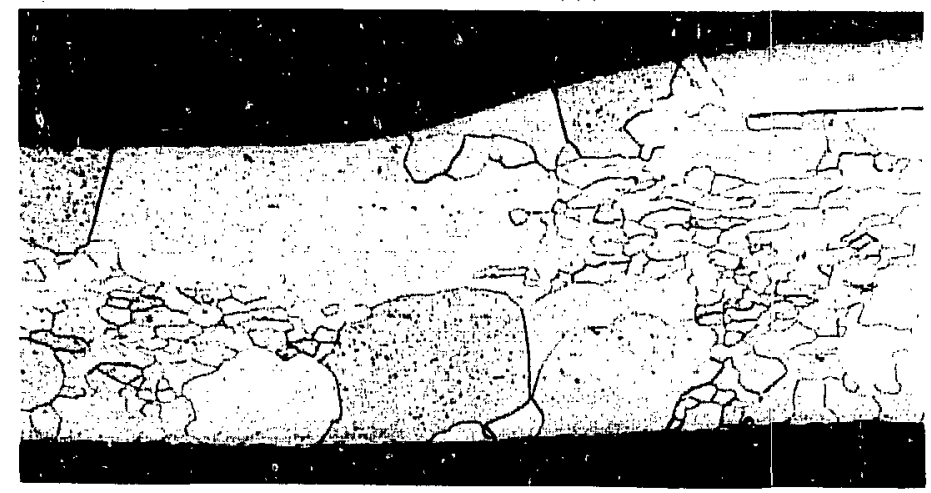

Fig. 30. Significant grain coarsening occurred on one side of the FC-604 vent cover weld; $50 \mathrm{X}$. 